\title{
Taphofacies and Petrofacies Theoretical Marine Models Applied to the Coquina of the Amaral Formation (Lusitanian Basin, Portugal)
}

\author{
Gustavo Gonçalves Garcia ${ }^{1}$, Antônio Jorge Vasconcellos Garcia ${ }^{1,2}$, Maria Helena Paiva Henriques ${ }^{1, *(D)}$, \\ Rafael Mendes Marques ${ }^{1}$ and Rui Pena dos Reis ${ }^{1}$ (iD) \\ 1 Geosciences Center, Department of Earth Sciences, University of Coimbra, Rua Sílvio Lima, \\ 3030-790 Coimbra, Portugal; gustavogarcia@dct.uc.pt (G.G.G.); ajvgarcia@academico.ufs.br (A.J.V.G.); \\ uc2017257788@student.uc.pt (R.M.M.); penareis@dct.uc.pt (R.P.d.R.) \\ 2 Progeologia Laboratory/Nucleus of Competence in Oil, Gas and Biofuels, Federal Universiy of Sergipe, \\ Avenida Marechal Rondon S/n, São Cristóvão 49100-000, Sergipe, Brazil \\ * Correspondence: hhenriq@dct.uc.pt; Tel.: +351-919-721-820
}

check for updates

Citation: Garcia, G.G.; Garcia, A.J.V.; Henriques, M.H.P.; Marques, R.M.; Pena dos Reis, R. Taphofacies and Petrofacies Theoretical Marine Models Applied to the Coquina of the Amaral Formation (Lusitanian Basin, Portugal). J. Mar. Sci. Eng. 2021, 9, 1319. https://doi.org/10.3390/ jmse9121319

Academic Editors:

George Kontakiotis,

Assimina Antonarakou

and Dmitry A. Ruban

Received: 20 October 2021

Accepted: 18 November 2021

Published: 23 November 2021

Publisher's Note: MDPI stays neutral with regard to jurisdictional claims in published maps and institutional affiliations.

Copyright: (c) 2021 by the authors. Licensee MDPI, Basel, Switzerland. This article is an open access article distributed under the terms and conditions of the Creative Commons Attribution (CC BY) license (https:/ / creativecommons.org/licenses/by/ $4.0 /)$.
Abstract: The Amaral Formation has a wide geographic distribution within the Lusitanian Basin, at the western Iberian Margin (Portugal). The different depositional contexts for this unit enabled the distinction of three sectors: lagoon, lagoon-barrier, and marine-distal. The integration of the evolutionary taphonomic analysis of its fossil assemblages with the analysis of multiscale properties through the CAMURES methodology (Multiscale Reservoir Characterization) allowed the application of a methodology for the classification of coquina which was previously developed for the Morro do Chaves Formation (Sergipe-Alagoas Basin, Brazil). Here, it was adapted according to the complexity of the Amaral Formation deposits. The classification of ten taphofacies, in association with four lithofacies, allowed the definition of 84 petrofacies, based on the nature of the sedimentary and taphonomic processes. The relationship between the structural context, the systems tracts, the diversity of the fossil record, the classification of taphofacies and petrofacies, and the understanding of vertical and lateral variations of the sediments' deposition within the unit support the construction of geological and theoretical models for coquina deposits. These models will allow for prediction of the spatial distribution of facies in other coquina analogous hydrocarbon reservoirs, as well as specifying the delimitation of reservoir zones for 3D geocellular modeling and flow simulation of hydrocarbon-producing reservoirs, thus improving predictive analyses.

Keywords: coquina taphofacies/petrofacies; Amaral Formation; Lusitanian Basin (Portugal); Upper Jurassic; carbonate reservoirs; theoretical models; paleoenvironmental models; paleogeographic reconstructions

\section{Introduction}

The need for increasing accuracy and effective predictive models is an important challenge faced by the oil industry, which seeks to understand the distribution of permoporous spaces in hydrocarbon reservoirs. In this context, multidisciplinary/multiscale studies on carbonate rocks, especially those formed by concentrations of fossils (coquina), have been developed, aiming for a better understanding on pre-salt reservoirs in the Brazilian Atlantic Border Basins, namely, in the Santos and Campos Basins [1,2].

The integrated analysis involving the characterization of petrofacies and the taphonomic approach based on the evolutionary taphonomy concepts and methods [3,4], with the application of the Multiscale Characterization Methodology of Reservoirs-CAMURES [2,5], represents a new pathway for the development of predictive modeling of reservoir quality. By improving the understanding of the lateral and vertical facies variations of the coquina deposits, this integration allows us to expand the knowledge about the genesis of paleoenvironmental models, as well as the $3 \mathrm{D}$ geocellular models of coquina facies, which underlie the fluid flow simulation in hydrocarbon reservoirs [6-9]. 
The recognition of taphonomic alteration mechanisms in the fossil assemblages of the Amaral Formation (Kimmeridgian-Tithonian, Lusitanian Basin, Portugal), such as biodegradation, disarticulation, dispersion, reorientation, abrasion, dissolution, cementation, neomorphism, and recrystallization, with the resulting textural patterns (degree of fragmentation of skeletal remains, matrix type, and pore types) enabled the characterization of different taphofacies, associated with different petrofacies [10-13]. The approach applied in this work for fossil assemblages and other nonbioclastic elements refers to a classification system for coquina reservoirs based on bioestratinomic and fossil-diagenetic processes, and not only on the resulting products [13].

The Amaral Formation coquina deposits display high diversity in terms of fossil record and a very complex genesis. The application of the methodology previously developed for the classification of taphofacies and petrofacies of the Morro do Chaves Formation [13] to the Amaral Formation required an adjustment in order to incorporate the interaction between the taphonomic mechanisms, the tectonic-structural context of the basin, and the diversity of the fossil record and of the depositional environments inherent in these coquina deposits. In addition to the validation of the classification system and theoretical models for coquina deposits, the wide paleogeographic distribution of the Amaral Formation throughout the Lusitanian Basin and the large number of outcrops and control points allowed for the extrapolation of the analysis of the lateral variations of coquina deposits. The Amaral Formation represents an important cyclical depositional context, which includes coquina with high diversity, which are interspersed with fine silty-clay deposits from deeper areas, and with sandy deposits with fluvial origins. The possibility of analyzing the vertical and lateral variations, from the microscopic scale to the basin-wide scale, makes the Amaral Formation an essential reference on the extrapolation of theoretical models to coquina reservoir analogues.

The basin's context plays an important role in the application and refinement of the analogous model over the entire extension of the studied deposits. Considering the different sectors and corresponding evolutionary particularities, factors such as tectonism, uplifts, and tilting controlled the differentiation in substrate inclination and in facies distribution. Transgressive and regressive events also play an important role in these carbonate and mixed-deposition systems.

\section{Geological Setting}

The sedimentation in the Lusitanian Basin was conditioned by its paleogeographic configuration represented by a NNE-SSW gulf, open to the south, where sediments from its steep east and west margins were drained, as well as from the north, through a distal fluviodelta system [14,15]. During the deposition of the Amaral Formation sediments, the paleoenvironmental evolution, somewhat carbonated, whether bioconstructed or not, was strongly affected by the substrate's positioning related to tectonism, as well as by the saliferous diapirs that generated intrabasin high bottoms, which favor concentrations of carbonate sediments. Sedimentation in the initial rift phase occurred in association with a transgressive event, changing, in the Late Kimmeridgian and Early Tithonian, to a regressive context. Then, the conditions for carbonate sedimentation in shallow waters were established in the basin, which corresponds to Sequences I 2 and I 3 of [13] of the Amaral Formation. The marine sedimentation conditions remained shallow, represented by an alternation of muddy, sandy, and carbonate sediments, configuring a lake into a deep marine environment with an expressive fossiliferous record [16]; towards the south, it gradually became deeper, drawing a large marine gulf.

During the Kimmeridgian in the proximal sectors (Boa Viagem and Alcobaça Formations), the sedimentation was predominantly continental; the distal sectors (Abadia Formation) record turbiditic fans. The deposition of the carbonate sediments from the Amaral Formation [17] and their relationship with other Upper Jurassic units is referred to as the upper Kimmeridgian-lower Tithonian boundary, framed in a tectonic context of sub-basin formation, which marks the post-climax of the rift [18,19] (Figure 1). 


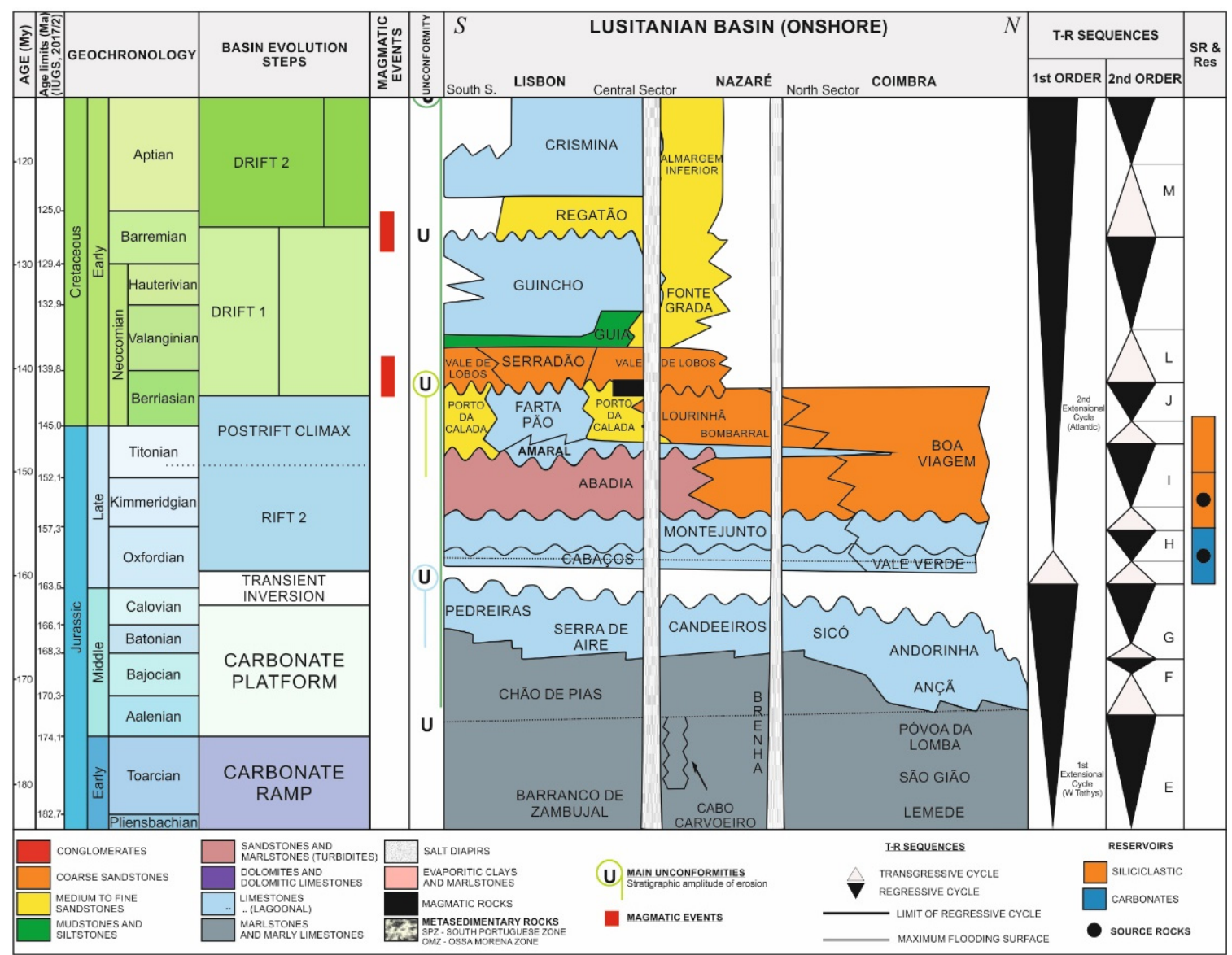

Figure 1. Stratigraphic framework of the Lusitanian Basin for the Pliensbachian-Aptian, i.e., discarding the underlying (RIFT 1 and marine invasion) and the overlying (DRIFT 3, inversion and uplift) intervals (modified after Pena dos Reis et al. [20]).

The carbonates of the Amaral Formation are composed of thin shallow marine deposits which are associated with a transgressive event. These carbonates cover the deep-sea sediments of the Abadia Formation, and, therefore, they can be considered as indicative of a significant decrease in bathymetry [21]. Pena dos Reis et al. [22] refer to this interval as facies of oolitic barriers and locally bioconstructed coquinoid reefs, represented by biofacies rich in fragments of echinoids, bivalves, stromatoporoids, spongy spicules, and microfauna (foraminifera, algae, and ostracods), and related to inter to infralittoral environments with clear marine influence [23]. Choffat [24] and Seifert [25] classified the Amaral Formation lithotypes as intraclastic limestones, dolomitic limestones, oolitic limestones, and conglomeratic limestones with intercalations of reef limestones.

Wilson [26] and Teixeira and Gonçalves [27] argued that the reef units which occurred from Montejunto to Tejo during the Kimmeridgian, whether of biostroma type or of bioherm type, correspond to lateral variations of the Amaral Formation, but with indefinite ages ("Corálico do Amaral", Ota Limestones, Monte Redondo Limestones, and Atouguia Limestones).

More recently, Leinfelder et al. [28] recognized the fossil diversity of the Amaral Formation reefs, as well as the paleoenvironmental implications of the corresponding distribution within the context of a mixed carbonated platform. These were developed during the Late Jurassic in the central-west region of Portugal, namely during the Kimmeridgian and Tithonian transgressive events, despite the limitations on using biostratigraphic tools (based on macro and microfossils) in the establishment of lateral correlations in reef deposits. In this sense, sequence stratigraphy seems to be the only method allowing the recognition of the depositional models for this interval in the Lusitanian Basin [29-34]. However, the sequence stratigraphy does not consider the different source areas and the basin structure, 
which can lead to distinct paleoenvironmental interpretations, such as the Ota Limestones and the Amaral Formation [28].

Fürsich et al. [35] describe and interpret, from the taphonomic and paleoecological points of views, the Upper Jurassic bivalve assemblages of these units from the central part of the Lusitanian Basin, outcropping between the regions of Torres Vedras and Nazaré. The authors consider that the development of bivalve concentrations is associated with phases of maximum flooding associated with coastal environments, with controlled salinity, being less common in open platform configurations. However, they also admit that, although rarely, they can also occur within a transgressive system. This happens when the remobilization of sediments is not as expressive as it is during the late transgression. Finally, the authors claim that several of the described concentrations are not restricted to the Lusitanian Basin, but also occur in other places in the epicontinental seas located in the north of the Neo-Tethys Ocean.

\section{Materials and Methods}

The Amaral Formation is recognizable throughout the Lusitanian Basin. Due to its wide geographical distribution and based on the depositional contexts interpreted in this work, the study area was divided into three sectors, namely, lagoon, lagoon-barrier, and marine-distal (Figure 2a,b). The lagoon sector covers the region between Leiria and Figueira da Foz, on the current coastal strip, extending to the latitude of Coimbra to the east. In this region, the Amaral Formation was analyzed through two stratigraphic sections: Cumieira (Pombal) and Abiul (Pombal). The lithofaciological and taphonomic analyses were carried out based on macroscopic descriptions of 58 samples: 53 from the Cumieira Section and five from the Abiul Section. Fifteen outcrops were also analyzed for lateral and vertical control of the units, and 41 samples were collected (Figure 2c,d).

The lagoon-barrier sector covers the region located between Lourinhã and Leiria, on the coastal strip, extending to the latitude of Batalha to the east. In this region, the Amaral Formation was characterized through the study of two stratigraphic sections: Praia do Salgado (Famalicão) and Praia da Consolação (Atouguia da Baleia). The lithofaciological and taphonomic analyses were performed based on macroscopic descriptions of $102 \mathrm{sam}$ ples, 61 from the Praia do Salgado Section and 41 from the Praia da Consolação Section. Two other outcrops were also analyzed for lateral and vertical control of the units and nine samples were collected (Figure 2e,f).

The marine-distal sector covers the region located between Cascais and Lourinhã, on the coastal strip, extending to the latitude of Ota to the east. In this region, the Amaral Formation was characterized through the study of one section: Pedralvo (Arruda dos Vinhos). The lithofaciological and taphonomic analyses of this section were carried out based on macroscopic descriptions of nine samples. Eight other outcrops were also analyzed for lateral and vertical control of the units, and eight samples were collected (Figure 2g).

The methodological approach presented in this work for the coquina of the Amaral Formation follows the methods applied by Garcia et al. [13] for the coquina of the Morro do Chaves Formation (Sergipe Alagos Basin, Brazil). However, it was necessary to adjust them for the characterization of petrofacies, considering the existence of other variables, namely, the higher diversity of fossil assemblages, as well as the influence of local tectonic constraints, and also the impacts of transgressive events when framed within a regressive context.

The classification of taphofacies and petrofacies proposed by Garcia et al. [13] is based on concepts and methods of evolutionary taphonomy [36]; it considers the description and identification of all taphonomic mechanisms, i.e., biostratinomic and fossil diagenetic. The principles grounding the CAMURES methodology [2,5] improve the understanding of taphonomic processes over time and space, thus contributing to deepen the knowledge regarding the porosity-permeability distribution in a lithostratigraphic unit. 


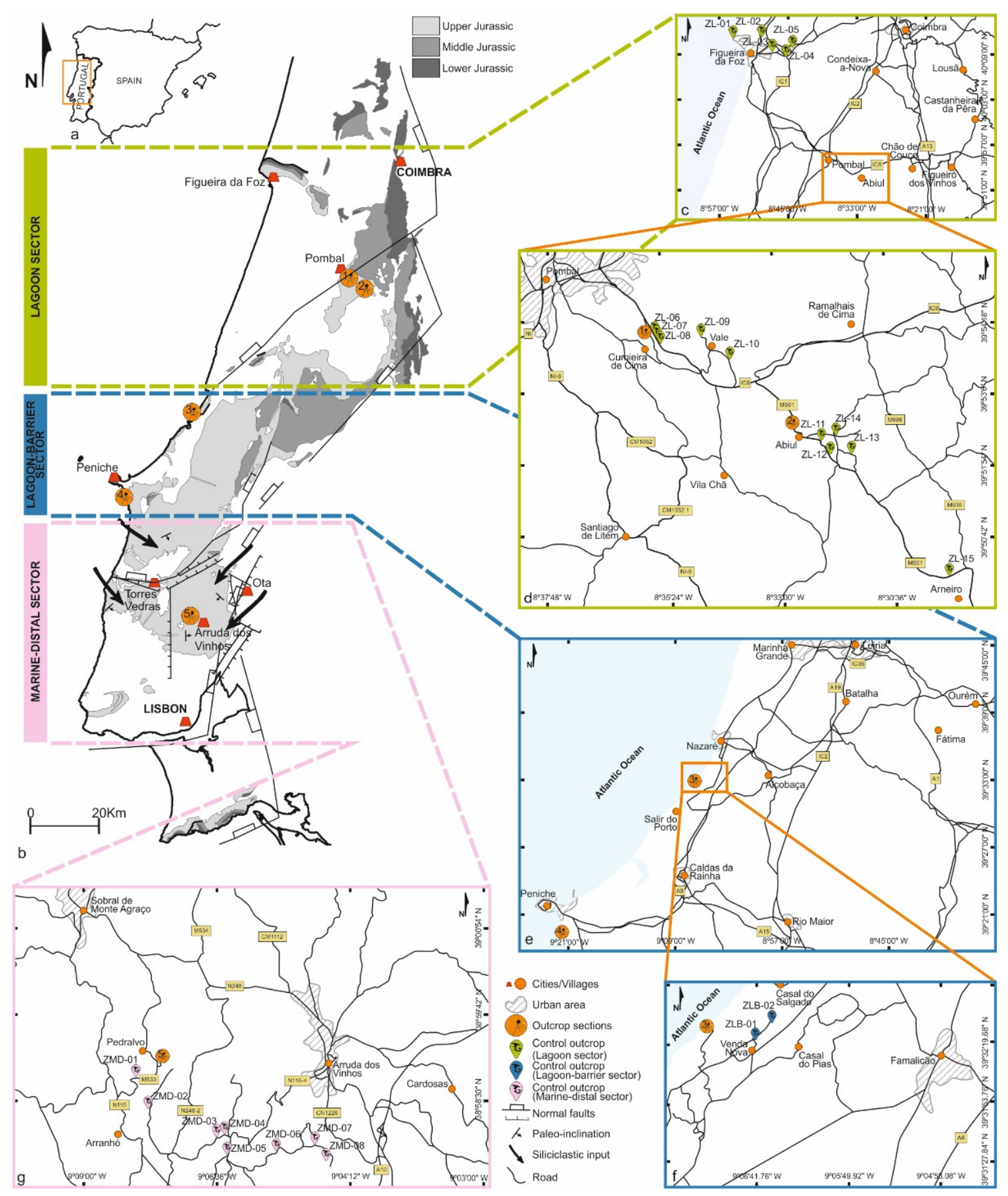

Figure 2. (a) Geographical location of the Lusitanian Basin; (b) Jurassic geological map of the Lusitanian Basin; (c) Location of the lagoon sector showing the Cumieira Section, the Abiul Section, and five control outcrops; (d) Location of the Cumieira Section, the Abiul Section, and ten control outcrops in detail; (e) Location of the lagoon-barrier sector showing the Praia do Salgado Section and the Praia da Consolação Section; (f) Location of the lagoon-barrier sector showing the Praia do Salgado Section and two control outcrops in detail; (g) Location of the marine-distal sector showing the Pedralvo Section and eight control outcrops.

The CAMURES methodology [2,5] consists of the integration of tools and data obtained at different observation scales (ranging from facies interpretation of rock samples to seismic interpretation of the basin) and in the representation of the heterogeneities existing in each of them. Thereby, an ideal geological model is obtained, both from the point of view of its genetic conception (conceptual geological model) and from the point of view of 3D geocellular modeling of properties. The CAMURES methodology assumes the recognition 
of the genetic processes, associated with their corresponding products/properties. The processes are classified in different scales of observation in a descriptive way. The analysis of processes and not just products/properties allow the transfer of information between scales. Thereby, the positioning of the petrofacies in the systems tracts and depositional sequences increases the accuracy of 3D geocellular facies models of the reservoir on the seismic scale.

In this context, a taphofacies/petrofacies definition is proposed for the hybrid coquina deposits of the Amaral Formation, based on the types and intensities of the identified sedimentary and taphonomic processes (Figure 3). Environmental energy is the primary control for the origin and distribution of petrofacies located in different "petrofacies clusters" (A, B and C) as shown in Figure 3. These clusters are individualized according to the nature of the interstitial material, being cluster (A) muddy carbonate matrix; cluster (B) terrigenous, coarse-grained siliciclastic material, and cluster $(\mathrm{C})$ dominance of fragments of broken carbonate bioclasts.

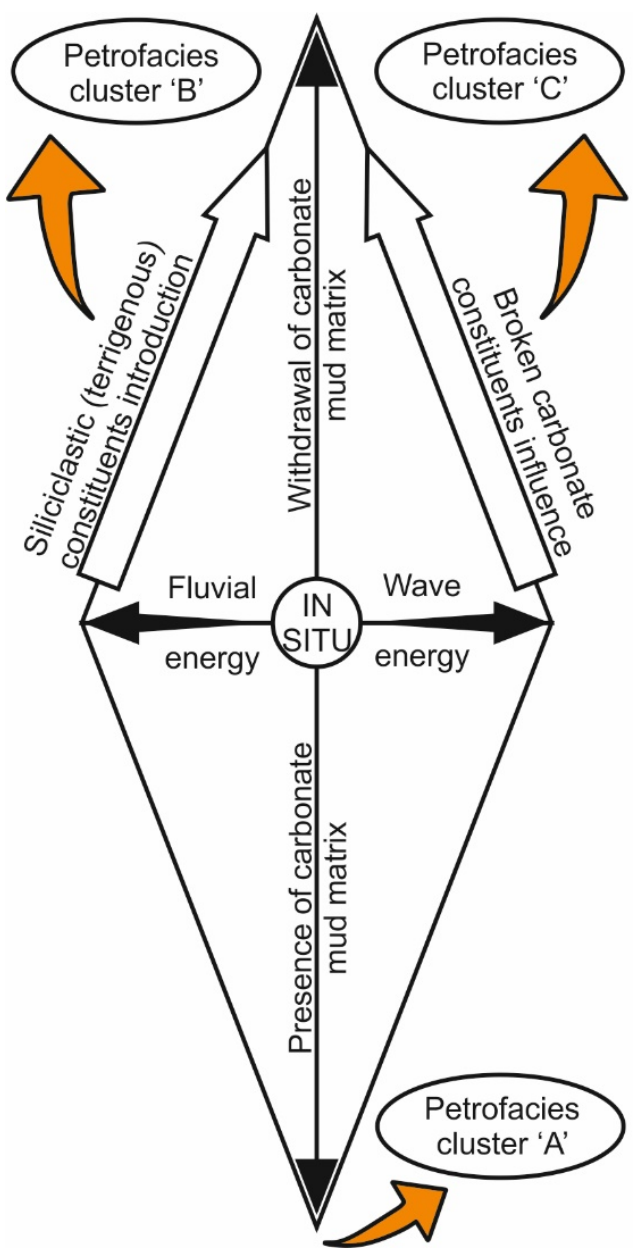

Figure 3. Environmental energy factors controlling the distribution of petrofacies characterized in this work which define the main petrofacies clusters (A, B and C) (according to Garcia et al. [13]).

The petrofacies designation used in this article follows the alphanumeric classification, designed with the goal of identifying types and intensities of processes and products associated with coquina [13]. The alphanumeric classification presented here aims to facilitate the understanding of facies types according to their petrographic and taphonomic characteristics. This proposal seeks to validate and emphasize the different recognized taphonomic processes and their relationship with depositional environments (Table S1). The facies distribution, according to the depositional environment and considering the origin and energy intensity (fluvial and wave) of the remobilization, is represented in Figure 4. 


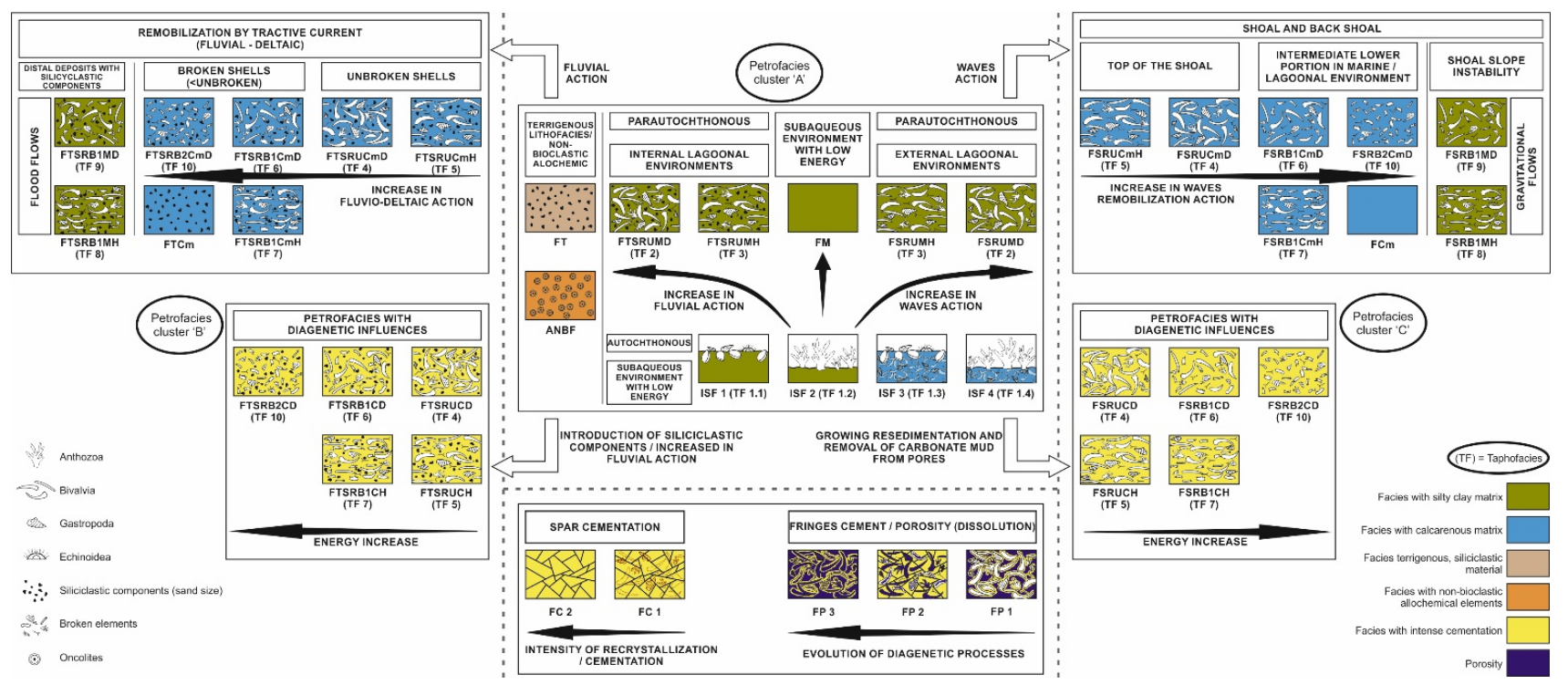

Figure 4. Petrofacies characterization and petrofacies clusters, associated with depositional environments, degree of remobilization, and fossil-diagenetic intensity (modified after Garcia et al. [13]).

The coquina petrofacies can be differentiated into two groups: coquina composed almost exclusively of representatives of a single taxon (e.g., bivalve coquina), and coquina made up of representatives of different taxa. In addition, coquina may consist of organically bounded elements (e.g., corals) and not organically bounded elements (e.g., bivalve). This faciologic/compositional distinction of coquina led to the creation of a terminology in addition to the alphanumeric classification previously described [13]. Letters are then used which resulted from the abbreviation of the type of organic relationship that exists between elements. This characteristic is expressed as described below, respectively: nobnot organically bounded elements (e.g., bivalve, gastropods); ob-organically bounded elements (e.g., coral reefs). Organically bounded elements are considered unbroken (U) only in the in situ facies (ISF), while in other contexts, they are always recognized as being broken $(\mathrm{B}, 1$ or 2$)$.

\section{Results}

The results for the macroscopic and taphonomic analyses of the Amaral Formation, framed in a multiscalar perspective, allowed the establishment of a stratigraphic evolutionary model for the Amaral Formation, based on the recognition of different facies according to their compositional, textural, and taphonomic properties. Thus, the analysis of different lithological and taphonomic aspects of the Amaral Formation sedimentary record resulted in the establishment of 10 taphofacies ( 1 to 10 , related to deposits with fossils) that, in association with four lithofacies $(1,2,4$ and 5, related to deposits without fossils, adapted from Garcia et al. [13]), allowed the definition of 84 petrofacies (Figure 4 and Table S2). The petrofacies characterization and petrofacies clusters, associated with depositional environments, degree of remobilization, and fossil-diagenetic intensity described in this work (Figure 4), illustrate in a synthetic way the characteristics of this type of deposit, not distinguishing, for example, if the elements are organically bounded or not organically bounded. Likewise, in the lithofacies and taphofacies classification of the coquina from the Amaral Formation, there are petrofacies that occur in more than one type of environment (eight in total; Table S2). For the taphofacies definition, the different mechanisms of taphonomic alterations that had acted on the fossil elements recorded in the coquina from the Amaral Formation, which are described below, were taken into consideration. 


\subsection{Mechanisms of Taphonomic Change in the Coquina of the Amaral Formation}

The high concentration and diversity of bioclasts and other allochemical constituents recorded in the Amaral Formation are the result of different long-lasting taphonomic mechanisms and of the conditions that controlled the different paleoenvironmental contexts to which these deposits are related. Taphonomic mechanisms recognized in the recorded elements and assemblages of the Amaral Formation include cementation (permineralization, formation of concretions), neomorphism (recrystallization), replacement, abrasion, dissolution, mechanical distortion, disarticulation, reorientation (dispersion and regrouping), and taphonomic removal or remobilization (accumulation and resedimentation). Taphonomic analysis of hand samples, together with fossil separation techniques, allowed the identification of the main taphonomic processes, which generally occurred in the following order: disarticulation, mechanical distortion and abrasion, reorientation (dispersion and regrouping), cementation (permineralization, formation of concretions) and neomorphism (recrystallization), and taphonomic removal or remobilization (accumulation and resedimentation).

\subsubsection{Disarticulation}

The disarticulation process is identified essentially in elements that are not organically bounded. This is one of the first processes to occur and is the most common, especially in environments subject to intense wave action. The elements recognized in the Amaral Formation present mainly two states of disarticulation: with the mollusca valves and/or echinoderm plates joined, but open, and slightly fragmented; or with all the elements disarticulated (spines and plates of echinoderms, mollusca valves, among others) (Figure 5a-d). The TF 1 taphofacies, usually related to muddy facies, is the only example in which the elements are complete.

\subsubsection{Mechanical Distortion and Abrasion}

The processes of mechanical distortion and abrasion occur simultaneously and result from the action of waves (normal or storm) and river flows. The degree of taphonomic alteration of these processes is defined by the duration of its activity and intensity. The mechanical distortion corresponds mainly to change in the size of elements by fragmentation, usually before abrasion [37]. The allochemical components of carbonate rocks (e.g., bivalves, gastropods, corals, among others) have naturally rounded surfaces. However, the abrasion process increases the roundness of these surfaces (Figure 5e,f). In the Amaral Formation deposits, elements are commonly recognized in two stages of fragmentation: totally or partially fragmented. Such situation is found in almost all petrofacies (Figure $5 \mathrm{~g}, \mathrm{~h}$ ), except for the TF 1 taphofacies. In turn, the mechanical distortion mechanism can be recognized for elements not organically bounded in TF 4.3, TF 5.3, TF 6, TF 7, TF 8.1, TF 8.2, TF 9.1, TF 9.2, and TF 10 taphofacies, and for organically bounded elements in TF 2.2, TF 3.2, TF 4.2, TF 4.3, TF 5.2, TF 5.3, TF 6, TF 7, TF 8, TF 9, and TF 10 taphofacies. However, it is not recognized in TF 2.1, TF 3.1, TF 4.1, and TF 5.1 taphofacies.

\subsubsection{Reorientation (Dispersion and Regrouping)}

The elements (organically bounded or not) may occur scattered in the deposits or display some pattern of regroupment. In both cases, these elements were subjected to different types of displacements with different origins: waves (normal or storm), fluvial (normal or flood discharges), induced currents, or gravitational flows. These agents tend to organize the elements in two ways: aligning them with a preferential orientation, imbricated or not (easier to recognize among not organically bounded elements), or dispersing them in a chaotic way. This process is, therefore, responsible for two aspects recognized in the described petrofacies: dispersion and regrouping. They were recognized in almost all taphofacies (Figure 6a,b) and are partially absent only in TF 1 and TF 2 taphofacies. 


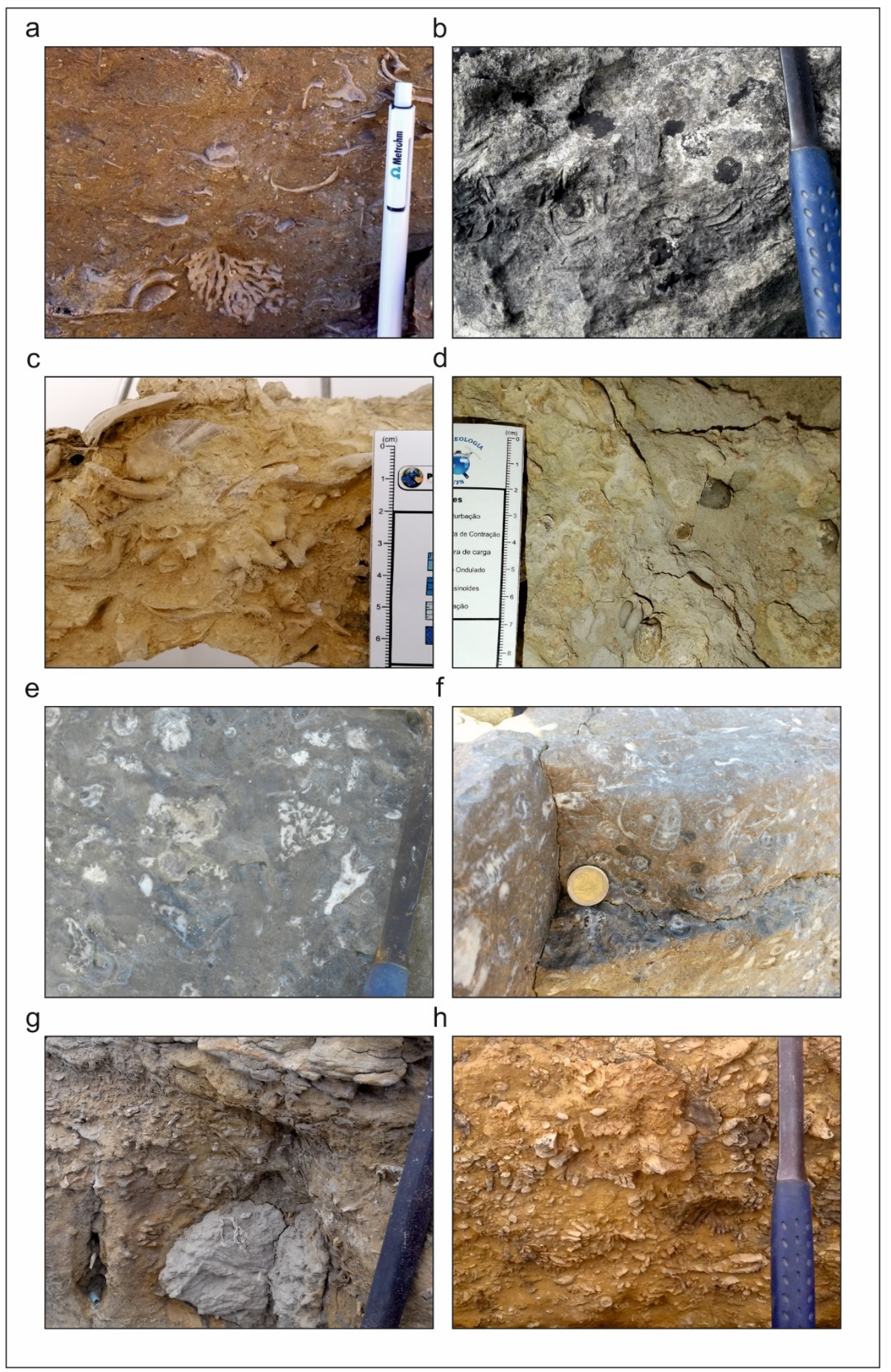

Figure 5. Photographs showing the results of different mechanisms of taphonomic alteration in coquina deposits, namely, (a) disarticulated elements with orientation; (b) unbroken elements with low fragmentation (partial); (c) unbroken and broken elements disarticulated with preferential orientation; (d) elements with chaotic orientation; (e,f) abrasion intense processes; (g) fragmentation intense processes; (h) fragmentation intense processes and important contribution of terrigenous constituents. 


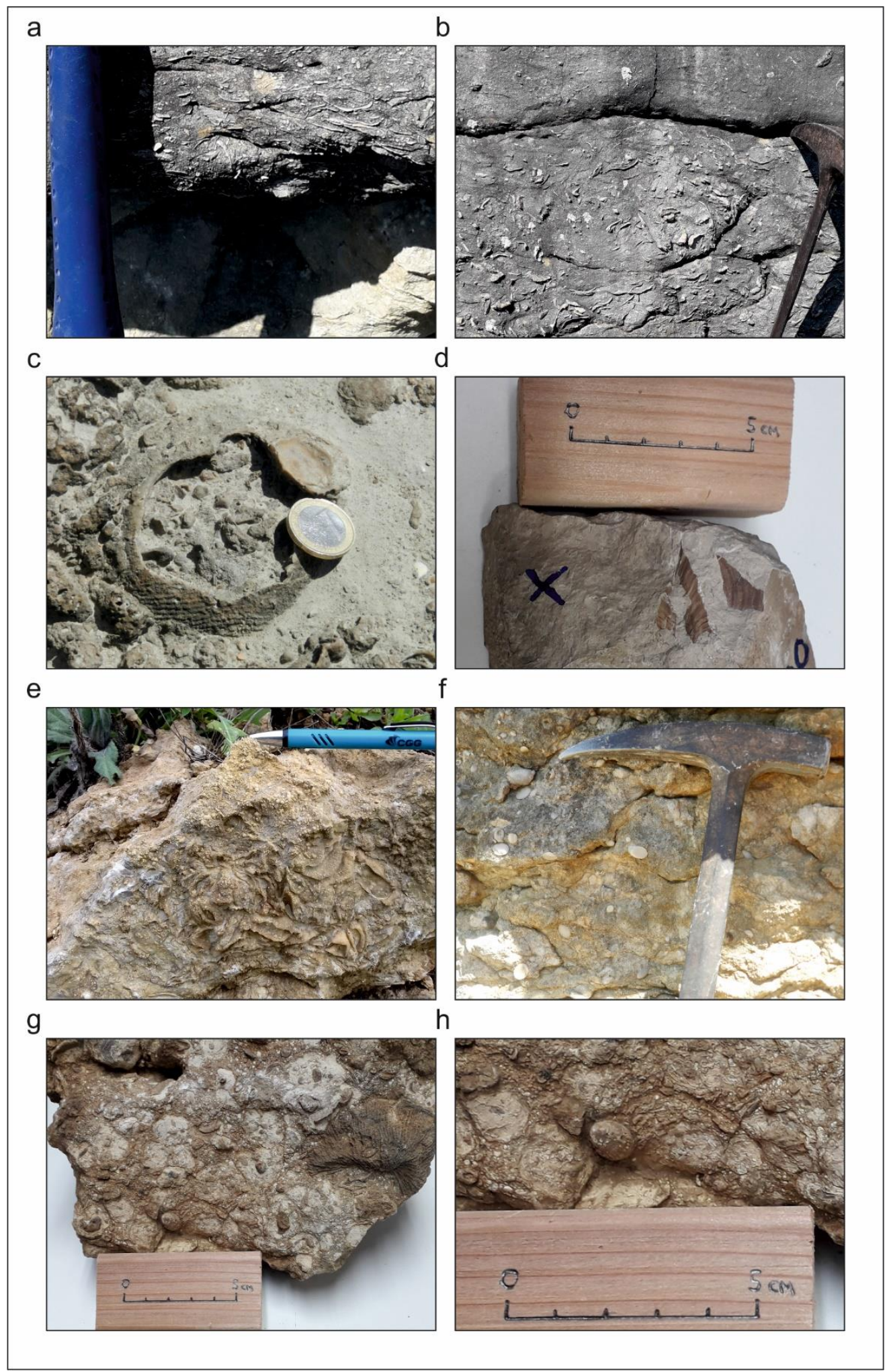

Figure 6. Photographs showing the results of different mechanisms of taphonomic alteration in coquina deposits, namely, (a) elements with orientation and/or imbrication; (b) elements with chaotic orientation; (c,d) micritization; (e) unbroken elements with joined valves, fragmented, and recrystallized; (f) recrystallization; $(\mathbf{g}, \mathbf{h})$ formation of concretions. 
4.1.4. Cementation (Permineralization, Formation of Concretions) and Neomorphism (Recrystallization)

Most of the allochemical constituents recognized in the Amaral Formation display a large size. In this context, the recognition of diagenetic processes can be performed through macroscopic analysis carried out in the field and in the laboratory. Diagenetic processes can be recognized in all taphofacies which, in this case, refer to neomorphism processes, namely micritization (Figure $6 \mathrm{c}, \mathrm{d}$ ) and recrystallization (Figure $6 \mathrm{e}, \mathrm{f}$ ). The first is recognizable in TF 1.1, TF 1.2, TF 2, TF 3, TF 8, and TF 9 taphofacies; the second, on the other hand, is particularly well represented in taphofacies that show complete and large not organically bounded elements, namely in TF 1, TF 2, TF 3, TF 4, and TF 5 taphofacies. The formation of concretions has been recognized in taphofacies related to low-energy environments. These occur due to an increase in the alkaline concentration around the elements and are usually related to the first stages of diagenesis; they occur in TF 4.3, TF 5.3, TF 6.3, TF 7.3, TF 8, and TF 9.3 taphofacies (Figure $6 \mathrm{~g}, \mathrm{~h}$ ).

\subsubsection{Taphonomic Removal or Remobilization (Accumulation and Resedimentation)}

Almost all the taphofacies described in this work present resedimented allochemical constituents. These are elements that correspond to skeletal remains that were subject to transport before the final burial in the sediments (Figure 7a,b); no evidence of taphonomic re-elaboration has been detected. The assemblages corresponding to lagoon and lagoonbarrier paleoenvironments are accumulated, which is attested by the occurrence of in situ elements of the Anthozoa Class in muddy facies (TF 1.2; Figure 7c-e)

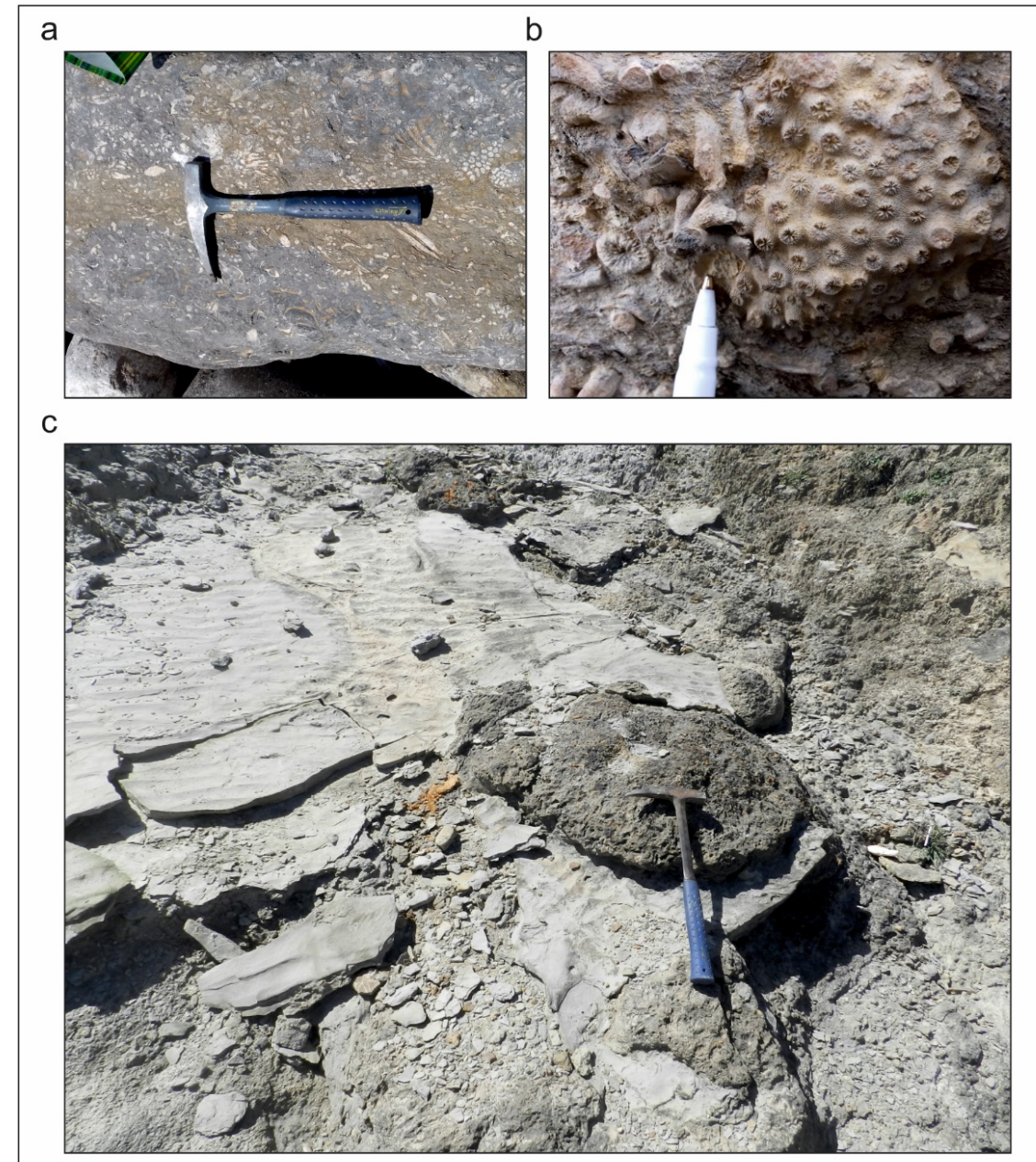

Figure 7. Cont. 
d

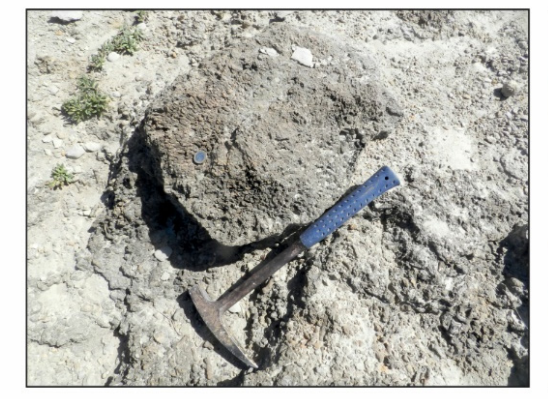

e

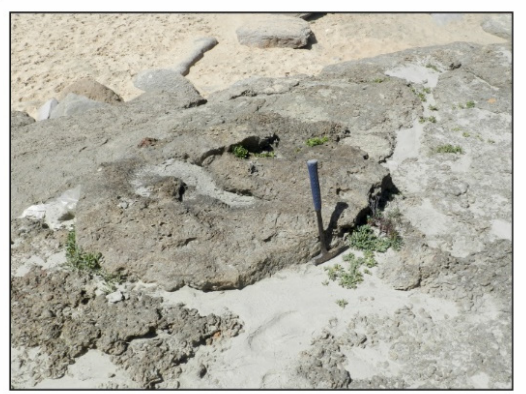

Figure 7. Photographs showing the results of different mechanisms of taphonomic alteration in coquina deposits, namely, (a) resedimented elements; (b) resedimented element with an excellent state of preservation; (c-e) accumulated Anthozoa class elements.

\subsection{Definition of Taphofacies and Petrofacies of the Amaral Formation}

For the Amaral Formation, and based on the identification of different lithological, taphonomic, and structural aspects, four lithofacies and 10 taphofacies were identified and characterized. Taphofacies 1 to 10 are related to a mixed clastic-carbonate platform and represent the biostratinomic and fossil-diagenetic processes that gave rise to the recorded elements (Table S2). Moreover, their spatial distribution reflects different sub-environments, and corresponding energy levels, across different platforms' contexts. Lithofacies 1,2, 4 and 5 correspond to deposits without fossils. Lithofacies 3 (sabkha) was classified for the Morro do Chaves Formation, but it was not identified for the coquina deposits of the Amaral Formation.

The integrated analysis of taphonomic and sedimentological data enabled the definition of 84 petrofacies. Among them, 53 display direct correlation with specific taphofacies (with bioclasts), three refer to lithofacies (without bioclasts), and 28 showing intense cementation, some of them with almost total replacement of the original constituents. The taphofacies and petrofacies' distribution, in association with the paleoenvironmental settings of the coquina record, lead to the differentiation of several depositional environments, in the context of a mixed platform.

\subsection{Stratigraphic Evolution Model for the Depositional Systems of the Coquina from the Amaral Formation}

The deposits of the Amaral Formation display important lateral variations. These are related not only to the dynamics inherent to each of the sub-environments where they are located, but also to the paleogeographic configurations recognized for the interval between the Kimmeridgian and the Tithonian. Due to these particularities, in this work, five distinct sequences widespread in three depositional environments were identified, namely, lagoon sector, lagoon-barrier sector, and marine-distal sector (Figure 2a).

\subsubsection{Lagoon Sector}

The lagoon sector is widely represented in most parts of the inland and the protected region of the large marine gulf, in which the Lusitanian Basin was formed at the time of deposition for the Amaral Formation sediments. The lagoon deposits surround the body of water; the occurrence of reef bodies or even barriers made up of bioclastic or oncolitic fragments protects it from the direct action of the waves. This depositional environment is widely expressed in the northern part, narrowing to the south with overlapping barrier islands and closer proximity to the uplifted basin margins (Berlengas and Ota). The Cumieira (Pombal) and Abiul (Pombal) sections and 15 outcrops for lateral and vertical control of facies represent this lagoon sector of the basin (Figure $2 b, c$ ).

Taking into consideration paleoecological, taphonomic, sedimentological, and stratigraphic criteria, five distinct sequences were identified for this sector, reflecting different depositional environments. 


\section{Lagoon-Barrier Sequence (Internal Lagoon Context)}

This first sequence is recorded only at the Pombal Section. It shows amalgamated layers with external lenticular geometry with lateral continuity. It consists of mudstones/wackstones, displaying plane-parallel and crossed stratifications truncated by waves, with ripple marks on the upper surface of some layers. Representatives of the Bivalvia and Gastropoda classes were recognized, supported by carbonate silty-clay matrix. At the bottom of this interval, oncolites up to $0.1 \mathrm{~mm}$ in diameter are also recorded. Fragments of carbonized fossil wood (between 0.1 and $1.1 \mathrm{~mm}$ ) are frequent along the whole sequence. FM and FSRUnobMD petrofacies were recognized in this sequence of the lagoon sector.

This interval corresponds to the most basal sequence of the Amaral Formation and is interpreted as representative of an internal lagoon environment with low energy, subject to normal waves, and far from the influence of the fluvial action, which can be attested by the large number of carbonized plant fragments transported to the lagoon. In the lagoon-barrier sector it is possible to laterally follow this sequence, namely, at the Praia do Salgado Section.

\section{High-Energy Transitional Sequence}

The second sequence is observed only at the Pombal Section. It presents external lenticular geometry with lateral continuity. The layers are composed of mudstones/wackstones (shales). Representatives of the Bivalvia and Gastropoda classes were recognized, supported by a silty-clay matrix with carbonate sand. They show ripple marks, plane-parallel stratification, and truncated stratification by waves. FM and FSRBnob1MD petrofacies were recognized in this sequence of the lagoon sector.

This second sequence of the Amaral Formation is interpreted as characteristic of a transitional environment, with moderate to high energy, subject to the frequent action of normal waves. In the lagoon-barrier sector it is possible to laterally follow this sequence at the Praia do Salgado and Praia da Consolação sections.

\section{Low-Energy Transitional Sequence}

The third sequence is observed only at the Pombal Section. It is composed of some amalgamated layers, with the thicker ones showing external lenticular geometry with good lateral continuity. The layers are made up of mudstones/wackstones. In general, they present wavy and crossed stratifications truncated by waves and ripple marks on the upper surface of some layers. Representatives of the Bivalvia and Gastropoda classes were recognized, supported by a silty-clay to very fine and carbonate sandy matrix. In the middle part of the sequence, some layers record rare fragments of carbonized fossil wood. FM, FCm, FSRBnob1CmD, FSRBnob1MD, and FSRBnob2MD petrofacies were recognized in this sequence of the lagoon sector.

The third sequence of the Amaral Formation is interpreted as representative of lowenergy depositional context, subject to the continuous action of normal waves. In the lagoon-barrier sector it is possible to laterally follow this sequence at the Praia do Salgado and Praia da Consolação sections.

\section{Lagoon-Barrier Sequence}

The fourth depositional sequence of the Amaral Formation is represented at the Cumieira and Abiul sections. Amalgamated layers show external lenticular geometry and thicker layers present good lateral continuity. At the base, the beds are made up of grainstone, containing representatives of the Bivalvia class in sandy matrix with grain-supported biofactory. Oncolites $(0.2$ to $2.5 \mathrm{~cm})$ are also recorded. The upper layers are made up of mudstones/wackstones, containing representatives of the Bivalvia and Gastropoda classes, in addition to rare oncolites, supported by a very fine, carbonate silty-clay matrix. They present wavy and crossed stratifications truncated by waves, with some layers displaying ripple marks at the upper surface. At the top of this sequence, Echinoidea spicules ( 0.8 to $1.3 \mathrm{~cm}$ ) and coral fragments (3.5 to $5.0 \mathrm{~cm}$ ) occur. FM, FCm, FSRBnob1CD, FSRBnob1MD, 
FSRUnobCmD, FSRBnob2MD, FSRUnobBob1CmD, and FSRBnob1Bob1CmD petrofacies were recognized in this sequence of the lagoon sector.

The occurrence of Echinoidea and coral fragments suggests a depositional context of fast sea level rise. This sequence is laterally recognized in all sectors except at the Praia do Salgado Section.

\section{Lagoon Alluvial-Deltaic Sequence}

The top of the stratigraphic record is identified at the Cumieira and Abiul sections and displays limited exposure. It is represented, from the bottom to the top, by a layer of medium to fine sandstone, followed by amalgamated layers of grainstones, packstones, and wackstones, whose main component is oncolites with dimensions ranging from 0.1 to $1.0 \mathrm{~cm}$, and, finally, a sandstone layer, containing dispersed bivalves, which marks the starting of a new regressive cycle. FCm and FT petrofacies were recognized in this sequence of the lagoon sector.

The top of the stratigraphic sequence described in the lagoon sector clearly shows the transition between the carbonates of the Amaral Formation and the sandstones of the Lourinhã Formation. This fifth sequence records the establishment of a lagoon environment with fluvio-delta input. This sequence is also laterally recognized at the Praia do Salgado Section in the lagoon-barrier sector.

\subsubsection{Lagoon-Barrier Sector}

The lagoon-barrier sector corresponds to the narrowing, towards the south, of the lagoon located to the north of the basin. It is characterized by the occurrence of expressive reef bodies, as well as barrier islands, composed of bioclastic or oncolitic fragments. It is noteworthy, in this sector, to mention the occurrence of coarser continental sediments, coming from the uplifted margins of the basin (Berlengas to the west, and Ota to the east). In this region, the Amaral Formation was analyzed based on the study of the Praia do Salgado (Famalicão) and Praia da Consolação (Atouguia da Baleia) sections and two outcrops for lateral and vertical control of facies (Figure 2d,e).

In this context, and based on paleoecological, taphonomic, sedimentological, and stratigraphic criteria, five distinct sequences reflecting different depositional environments were recognized in this sector.

\section{Lagoon-Barrier Sequence (Regressive Context)}

This sequence is observed only at the Praia do Salgado Section. It consists of layers with amalgamated external lenticular geometries of wide lateral continuity, composed of grainstones, packstones, and mudstones. They present plane-parallel and crossed stratifications. In this sector, the top of the sequence is represented by a scraping surface, where dinosaur footprints are found. Representatives of the Anthozoa, Bivalvia, Gastropoda, and Echinoidea classes were also recognized, predominantly supported by a medium to fine, carbonate sand matrix. Locally, at the base of some layers, oncolitic levels occur.

FM, FSRBnob1Bob2MD, FSRBnob1CmD, FSRBnob1Bob1CmD, FSRBnob2CmD, and $\mathrm{FCm}$ petrofacies were recognized in this sequence of the lagoon-barrier sector.

This is the first sequence of the Amaral Formation, and it represents a depositional system of lagoon-barrier in a regressive context. Its upper surface records dinosaur footprints, which suggests proximity to the coastline at the end of this sequence. This sequence is also laterally recognized at the Cumieira Section of the lagoon sector.

\section{High-Energy Transitional Sequence}

The second sequence in the lagoon-barrier sector is recognized at the Praia do Salgado and Consolação sections. It is composed of amalgamated layers with external lenticular geometries and wide lateral continuity. They consist of packstones, wackstones, mudstones, and sandstones. It presents grooved and herringbone cross stratifications. Fragmented Anthozoa and Bivalvia representatives occur, predominantly supported by a medium to fine, 
carbonate sandy matrix, as well as carbonized fossil wood fragments and truncated wave stratification. FT, FM, FCm, FTC, FTCm, FSRUnobMH, FSRBnob1CmD, FSRBnob2CmD, FTSRBnob1CmD, FTSRBnob2CmD, and FSRBnob2Bob2CmD petrofacies were recognized in this sequence of the lagoon-barrier sector.

This second sequence is interpreted as characteristic of a transitional environment of moderate to high energy, subject to normal waves and occasional storms and to fluvial influence, that transported carbonized wood fragments to the lagoon. This sequence is also recognized laterally in the Cumieira Section in the lagoon sector.

\section{Low-Energy Transitional Sequence}

This sequence is represented in all the described sections of the lagoon-barrier sector. It is composed of layers displaying external lenticular geometry and wide lateral continuity including grainstones, packstones, wackstones, mudstones, and sandstones with planeparallel, rippled, and crossed truncated stratification. Anthozoa, Bivalvia, Gastropoda, and Echinoidea fragments are supported by a silty-clay to very fine carbonate matrix, locally rich in oncolites up to $4.0 \mathrm{~cm}$ and fossil wood with cross-bedding and herringbone cross-bedding. Bioturbations are found (Thalassinoides) with more incidence at the top of some layers, and accumulated corals occur in isolated levels. FM, FT, FCm, FSRUnobCmD, FSRBnob2MD, FSRBnob1Bob2MD, FSRBnob1Bob2CmD, FSRBnob1Bob2CD, FSRBnob2Bob2CmD, FSRBnob1CmD, FSRBnob2CmD, FSRBob1CmD, ISF 4 (TF 1.4), FSRBnob1Bob2CmH, FSRBnob1Bob1CmH, FTSRBnob2Bob1CmH, FTSRBnob1Bob2CmH, FTSRBnob1CmD, FTSRBnob1CmH, FTSRBnob2CmD, and FTSRBnob2Bob2CmD petrofacies were recognized in this sequence of the lagoon-barrier sector.

This sequence is characterized by the significant abundance of oncolites and is interpreted as representative of a low-energy context, under continuous action of normal waves. The input of fragments of fossil wood from the continent, located close to the west, persists; they were distributed among the sediments of the lagoon by the action of currents. The abundance of echinoderm spines suggests the occurrence of a transgressive event subsequent to the low-energy environment related to the previous sequence. Within this sector, it is recognized that there is a wide lateral variation over a relatively short distance. In a general context, the deposits described for the Praia do Salgado Section, in the northernmost portion of this sector, present facies with a calcarenitic matrix, without significative input of terrestrial constituents and with chaotic distribution of fossil elements. They represent a more protected region within the lagoon-barrier sector. On the other hand, the deposits described for the Praia da Consolação Section, in the southernmost portion of this sector, present facies with higher input of terrestrial constituents, higher cementation rates, and slight orientation of the fossil elements. They represent a more open region in the lagoon-barrier sector. This sequence is also recognized laterally in the Cumieira Section in the lagoon sector.

\section{Lagoon-Barrier Sequence}

This sequence can only be observed at the Praia da Consolação Section. It is composed of a thick set of layers displaying external lenticular geometries, with amalgamated lenses and wide lateral continuity. They consist of packstones, wackstones, and mudstones, and present plane-parallel and crossed stratifications truncated by waves. At some levels, desiccation cracks are seen at the top, and on one of these levels, dinosaur footprints are recognized. The occurrence of Anthozoa, Bivalvia, and Gastropoda representatives were also recognized, predominantly supported by a silty-clay, carbonated matrix. Rare fragments of fossil wood occur. FM, FCm, FTSRBnob2Bob2CmD, FTSRBnob2CmD, FSRBnob2Bob1MD, FTSRBnob1CH, and FTSRBnob2CH petrofacies were recognized in this sequence of the lagoon-barrier sector.

This sequence is interpreted as characteristic of a low-energy depositional lagoon environment, subject to the action of normal waves, and located near to the coast as 
suggested by the dinosaur footprints. This sequence is laterally recognized in all sectors apart from the Praia do Salgado Section.

\section{Lagoon Alluvial-Deltaic Sequence (Transgressive Context)}

The fifth sequence can only be recognized at the Praia do Salgado Section. It consists predominantly of mudstones intercalated in sandstones and calcarenites, containing Anthozoa and Bivalvia representatives. FT, FM, ISF 4 (TF 1.4), and ISF 2 (TF 1.2) petrofacies were recognized in this sequence of the lagoon-barrier sector.

This sequence is interpreted as characteristic of low-energy lagoon depositional environment, subject to normal waves and river systems, which would transport fragments of fossil wood to the lagoon. It is also recognized laterally at the Cumieira and Abiul Sections of the lagoon sector.

\subsubsection{Marine-Distal Sector}

The marine-distal sector is located in the southernmost portion of the large marine gulf; it corresponds to a failed and tilted basin bottom, with rift shoulders and highs produced by salt diapirism mainly during the beginning of Late Jurassic. These internal highs favor the formation of isolated platforms where coral bioconstructions and calcareous banks were installed, due to the intense action of waves and to the proximity of the open ocean. In this region, the Amaral Formation was analyzed based on the study of the Pedralvo (Arruda dos Vinhos) Section and on ten outcrops for lateral and vertical control of the facies (Figure 2f).

It consists of one sequence, defined considering paleoecological, taphonomic, sedimentological, and stratigraphic criteria, which reflects a specific depositional environment within the genetic context of the unit.

\section{Lagoon-Barrier Sequence (in a Marine-Distal System)}

This depositional sequence described for the Amaral Formation was recognized at the Pedralvo Section. It is composed of layers with external lenticular geometry and wide lateral continuity, easily observed in the thicker ones. They are constituted, from the base to the top, by mudstone with ripple marks and terrigenous constituents; wackstone containing Bivalvia representatives, ripple marks, and abundant terrestrial constituents; mudstone, containing rare echinoderm spines and bivalves; wackstone, with bivalves up to $7.0 \mathrm{~cm}$, some of them with joined valves; grainstone Anthozoa, Bivalvia, and Gastropoda representatives; grainstone with rare echinoderm spines and abundant complete bivalves up to $4.0 \mathrm{~cm}$; and grainstone with abundant echinoderm spines. FM, FTSRUnobMD, FSRUnobMD, FTSRUnobCmD, and FTSRBnob1Bob1CmD petrofacies were recognized in this sequence of the marine-distal sector.

The deposits described in this sequence are interpreted as generated in a context of fast sea level rise, which is corroborated by the occurrence of fragments of echinoderm spines. This sequence is laterally recognized in all sectors except for the Praia do Salgado Section.

\subsection{Paleoenvironmental and Paleogeographic Reconstructions}

The depositional systems that originated the sediments that comprise the Amaral Formation, in space and time, resulted from a quite-complex sedimentary dynamic with tectonic control and variation of the global sea level. The different depositional systems recognized at the Kimmeridgian-Tithonian transition in the Lusitanian Basin are conditioned by specific paleoenvironmental/paleogeographic contexts in each sector of the same basin. These constraints lead to a matrix of associations of characteristic facies (Table S3).

The stratigraphic correlation of the Amaral Formation sections, considering the transgressive-regressive cycles, allows for the understanding of the coquina record for this interval in a context of distinct depositional environments. These environments are framed in a large gulf paleogeography showing a very heterogeneous configuration (Figure 8). 


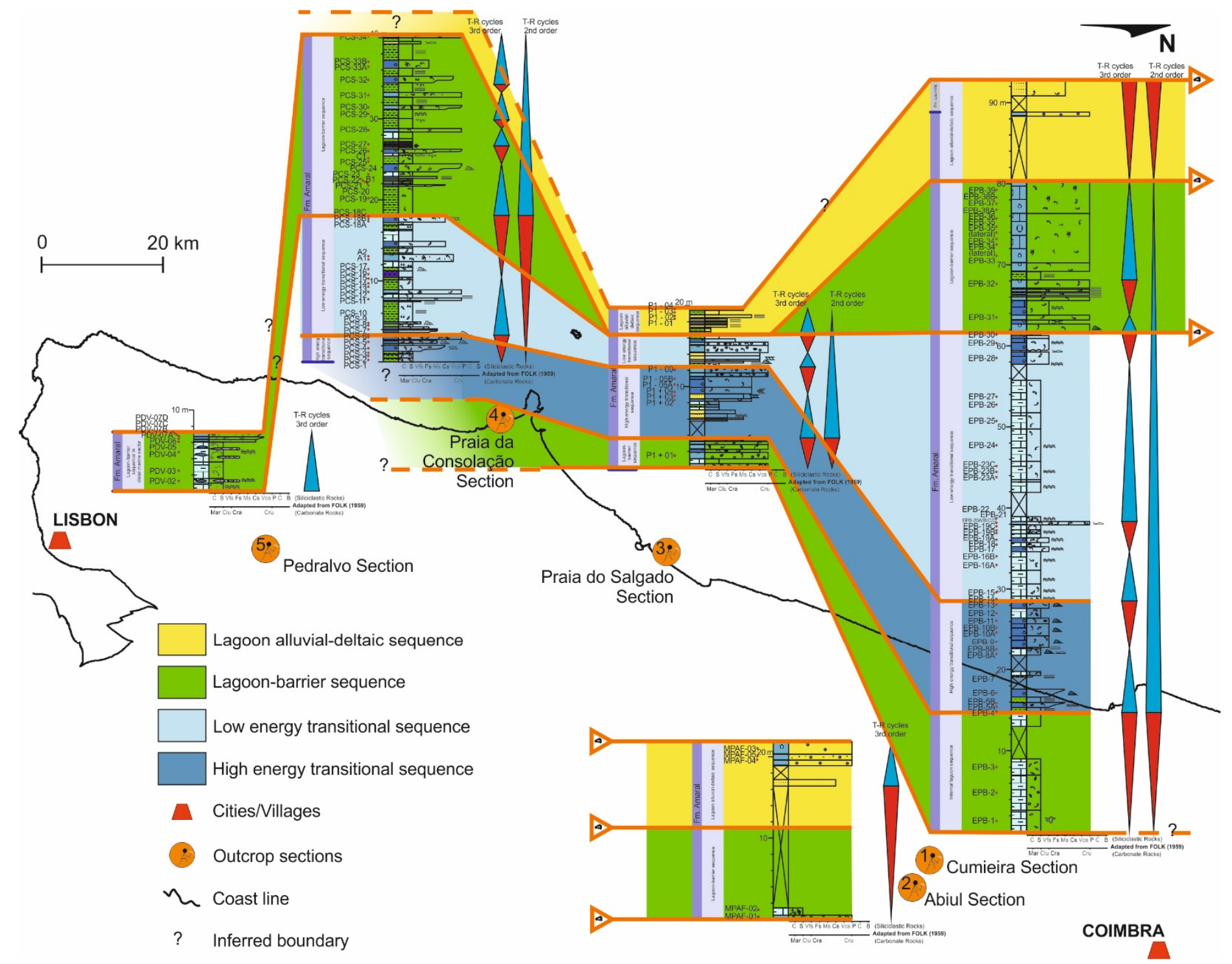

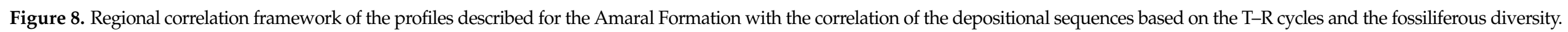


In each sector, the dominant energy conditions modeled different types of paleoenvironments (Figure 9). The lagoon, which corresponds to a low-energy environment protected by small and dispersed reef banks in the innermost part of the gulf, is represented by marginal and oncolitic facies with low input of terrestrial constituents (siliciclastic and carbonaceous).

The lagoon-barrier integrates two sub-environments. The first one is of low to medium energy, protected by a large number of aggregated and larger reef banks, located in the bay within the great gulf (north of the Berlengas structural high). It is represented by marginal oncolitic facies to reef facies (with in situ corals) with some contribution of terrigenous constituents. The second one corresponds to a high-energy environment, where a large number of coral banks was subject to major action by energetic agents (normal waves, storms, normal fluvial discharges, and runoffs). It corresponds to the proximal zone of the platform in the outer region of the gulf, and is represented by margins, reefs, washover, and alluvial-deltaic fans.

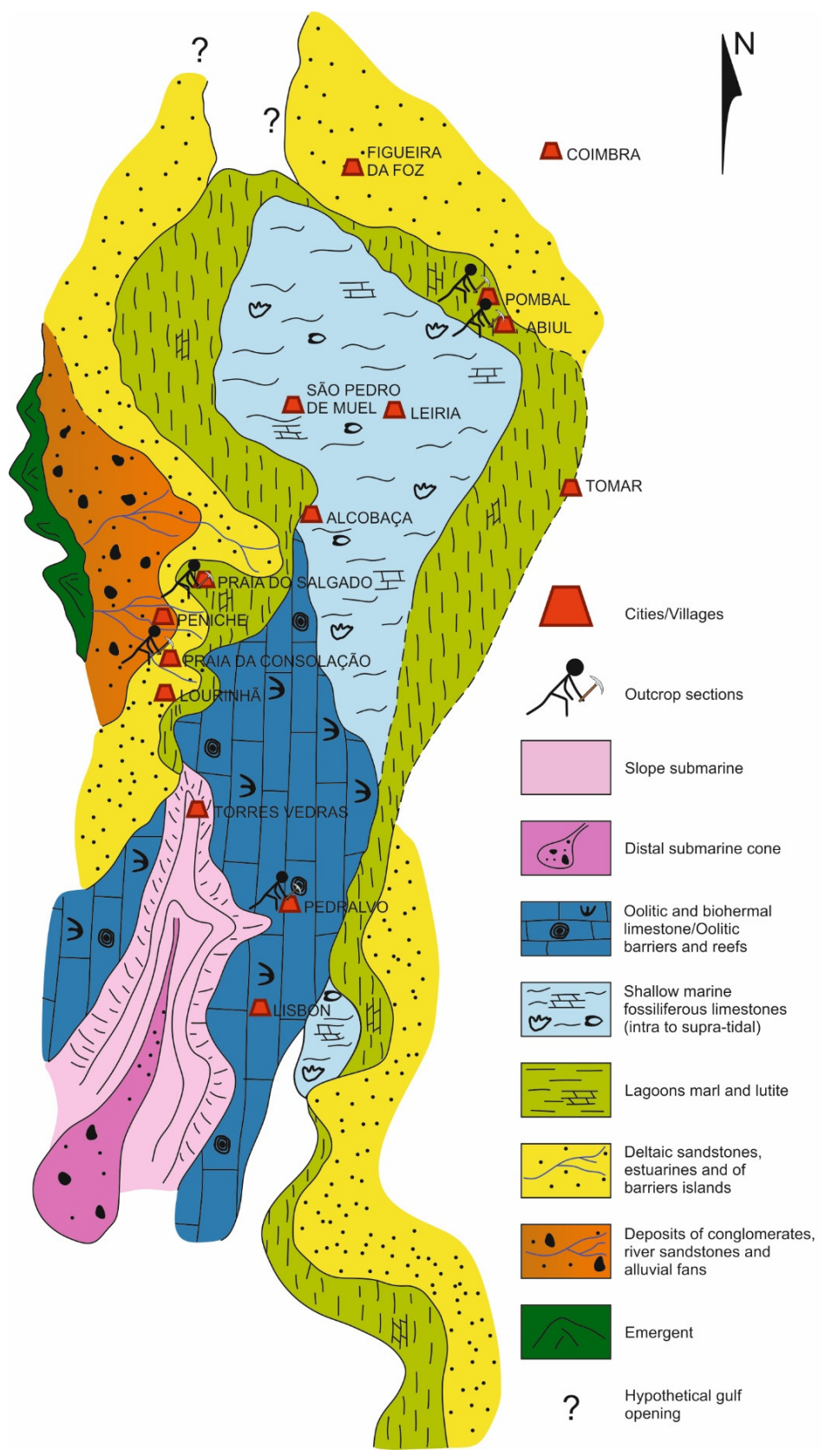

Figure 9. Paleoenvironmental sketch of the upper Kimmeridgian of the Lusitanian Basin (modified after Pena dos Reis et al. [38]; modified after Garcia et al. [39]). 
The marine-distal sector corresponds to an environment with wide energy variation (from very low to high). It is represented by isolated reef and marshal facies, with significant terrestrial contribution, as a direct result of the proximity of the source areas, whose distribution is limited to high structures along a platform with a steep slope. This environment corresponds to the distal zone of the platform in the outer region of the gulf.

The distribution of the coquina petrofacies, conceived according to the energy relations between the active sedimentary agents (fluvial energy and wave energy) for each sector, allowed the construction of a 3D paleoenvironmental model for the coquina of the Amaral Formation. This was strongly controlled by the taphonomic mechanisms, namely bioestratinomics, and reflects an evolutionary trend from a lagoon-barrier depositional system, influenced by fluvial inputs and sea level rise, to a lagoon alluvial-delta system, through high- and low-energy transitional episodes (Figure 10).

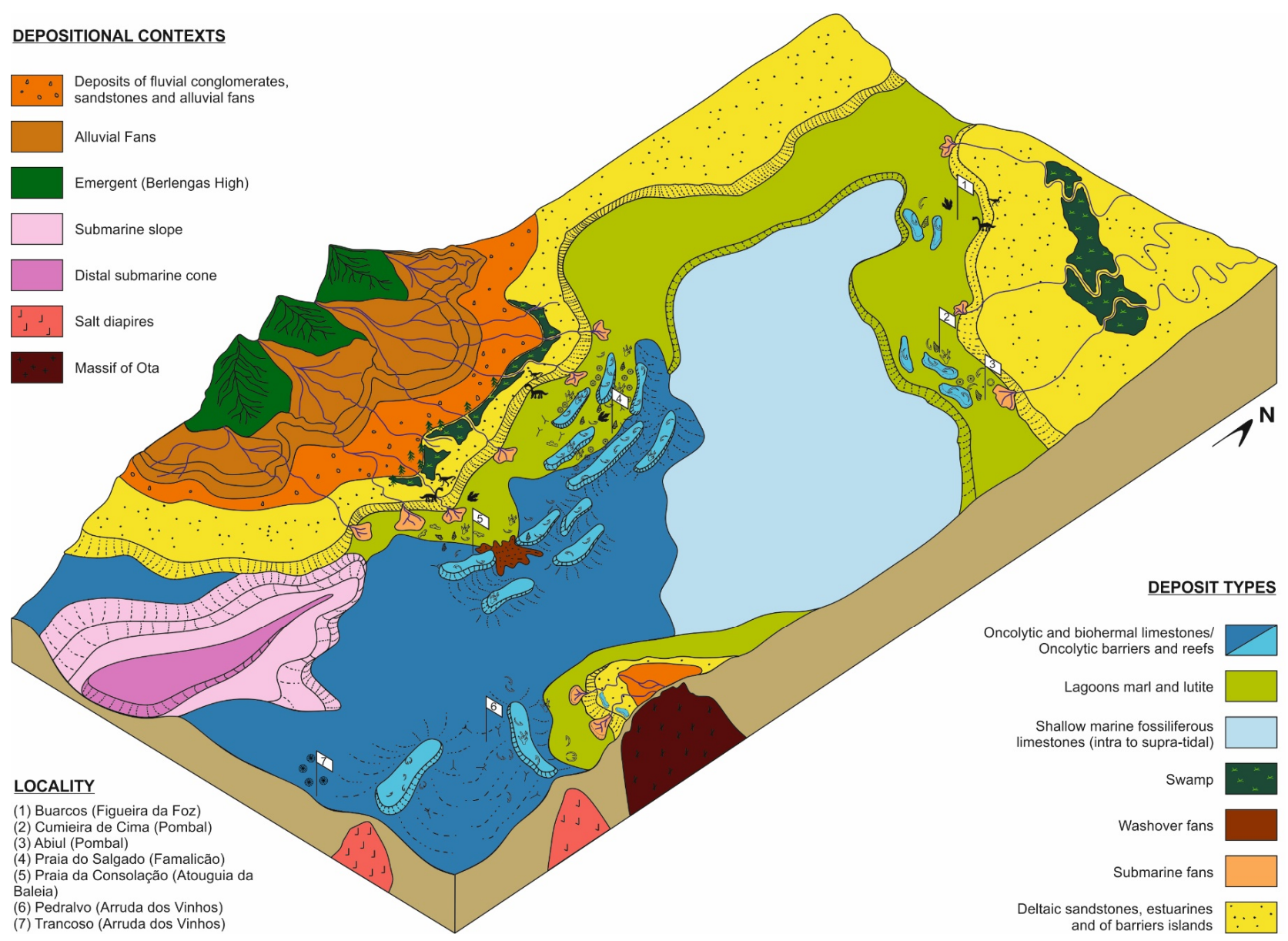

Figure 10. Paleoenvironmental/paleogeographic model showing the main types of sedimentary deposits and fossil records recognized in the studied areas.

The 3D model for the coquina of the Amaral Formation provides the basis for designing theoretical models of facies distribution. This model is capable of predicting the evolution of coquina facies within a mixed depositional system in the context of a heterogeneous platform (Figure 11). Such heterogeneity, due to the tectonic complexity of the Lusitanian Basin and its intense differential saliferous diapirism, results, regarding continuity, in two types of platforms: continuous (e.g., Pombal platform at SW, and Berlengas platform at E-SE), and isolated (e.g., Ota platform). 


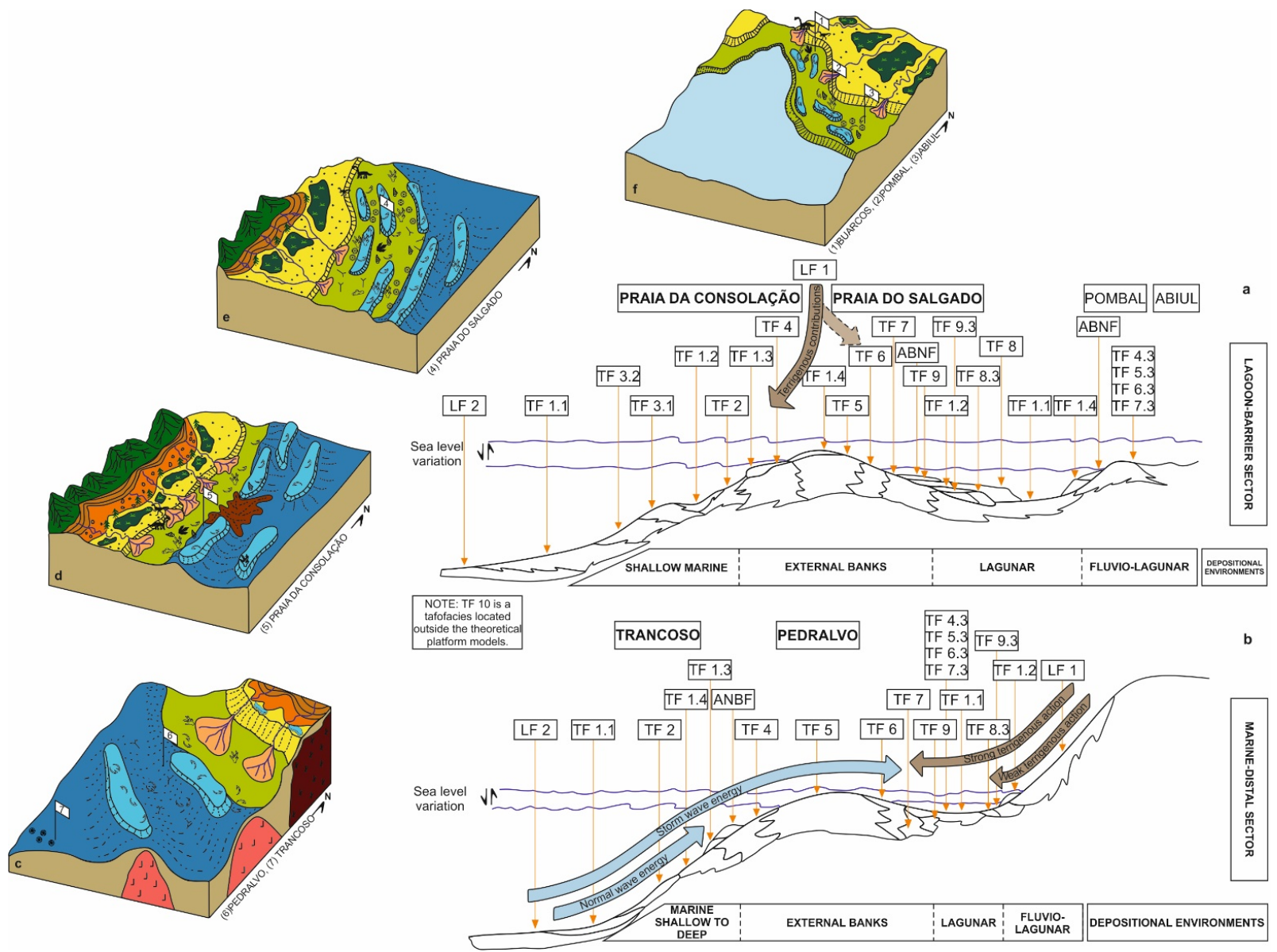

Figure 11. Theoretical models of distribution of taphofacies for the coquina deposits of the Amaral Formation in the context of a heterogeneous platform, namely, of two types: (a) continuous platform (e.g., Pombal platform for SW and Berlengas platform for E-SE); (b) isolated platform (e.g., Ota platform). Shown are 3D paleoenvironmental models of the depositional systems for the sectors studied based on the distribution of the taphofacies in the different sectors of the platform, namely, (c) depositional model of the marine-distal sector; (d,e) depositional models of the lagoon-barrier sector; (f) depositional model of the lagoon sector.

\section{Discussion}

The sedimentary infill of the Lusitanian Basin is related with the formation of a shallow/epicontinental sea at the beginning of the Jurassic [35], conditioned by intense tectonic activity and saline diapirism. The large lateral and temporal facies variations result from the structural complexity of the basin [20], which hinders the stratigraphic positioning of the recognized units; moreover, it makes it difficult to establish the lateral correlation between genetically distinct facies, which is particularly evident with regard to the units defined for the Upper Jurassic of the Basin, namely, for the Amaral Formation.

Choffat [40], studying the outcrops of the Torres Vedras and Montejunto region (i.e., the lagoon-barrier sector in this work), defined the Lusitanian stage as being constituted, from the base to the top, by three intervals: "Couches à Pholadomya protei", "Couches de Alcobaça", and "Couches à Lima alternicosta". Afterwards, he recognized that the marine sediments of the "Couches à Pholadomya protei" were analogous to those of the Oxfordian [41]; he redefines the Lusitanian stage as comprising only the "Couches de Alcobaça" and the "Couches à Lima alternicosta", to be of marine nature with "sequanian fauna", brackish, or lacustrine [41]. Later, Choffat [42] considers that the Lusitanian is composed of the "Calcaires de Montejunto" and "Marnes de Abadia", and defines, for the first time, the uppermost deposits of the Lusitanian, i.e., the upper part of the "Assise de Abadia", as "Corallien d'Amaral" $[43,44]$. The author describes the "Corallien d'Amaral" as a unit 
composed of carbonate deposits of small depth (intraclastic limestones, dolomitic limestones, oolitic limestones, and limestone conglomerates with reef limestone intercalations), represented by biofacies rich in fragments of echinoids, bivalves, stromatoporoids, spicules of spongiary, and microfauna (foraminifera, algae, and ostracods), and related to intertidal and coastal environments with clear marine influences [24].

In this work, the Amaral Formation is considered as composed of coquina, sandstones, and mudstones formed in the context of a mixed clastic-carbonate platform, spread within a wider region of the Lusitanian Basin, from Arruda dos Vinhos (south) to Pombal (north). The coquina deposits are made up of concentrations of elements that reflect different mechanisms of taphonomic alteration (fragmented, recrystallized, micritized, among others), namely, bivalves, gastropods, echinoderms (of echinoid spines and central body), corals, stromatoporoids, spongies, and microfossils (foraminifera, algae, and ostracods).

Leinfelder et al. [28] also recognized the faunal diversity of the Amaral Formation reefs in the Upper Jurassic record of the Lusitanian Basin, as well as the paleoenvironmental implications of their distribution in the context of a mixed carbonated platform. The authors consider that sequence stratigraphy seems to be the only method that can allow the design of depositional models for this interval in the basin [29-34]. However, this involves considering the different source areas and the structure of the basin. If these parameters are not considered, it may lead to paleoenvironmental interpretations that tend to define different lithostratigraphic units for deposits that, in fact, correspond to lateral variations of the same unit. This is the case, for example, of the Ota Limestone, considered so far as an independent unit [28], though a coeval of the Amaral Formation.

Finally, Fürsich et al. [35] consider the sedimentary record historically (and here also) assigned to the Amaral Formation as representing the Alcobaça Formation. Later, Fursich et al. [45] interpreted the Alcobaça Formation as related to a complex mosaic of lowto high-energy, carbonate- or siliciclastic-dominated shallow shelf settings; coastal embayments and lagoons; and coastal plains with rivers, lakes, and playas. Such interpretation regarding the depositional settings meets, in general, the different environments proposed here, but only for the central part of the Lusitanian Basin (between the Praia da Consolação and Praia do Salgado sections, i.e., the lagoon-barrier sector in this work).

As previously referred, the Amaral Formation presents a great diversity in terms of genetically distinct facies and fossil record. Thus, the application of the methodology to classify taphofacies and petrofacies developed for the Morro do Chaves Formation to the study of the Amaral Formation was adjusted in order to allow the integration of the interaction between the taphonomic mechanisms, the tectonostructural context of the Lusitanian Basin, the diversity of the recognized fossil record, and the depositional environments related to the coquina deposits.

As such, considering the paleoenvironmental distribution of the petrofacies model established by Garcia et al. [13] for the Morro do Chaves Formation, i.e., alluvial-fluvial/lacustrinesabkha, and considering the particular characteristics of the Amaral Formation, it is possible to relate this unit with lagoon, lagoon-barrier, and marine-distal environments.

From the taphonomic point of view, the coquina deposits of the Amaral Formation present higher variety of allochemical components (bioclastic and nonbioclastic), including different types of bioclasts and oncolites/oolites. In this sense, the representativeness of each of these components in the studied outcrops of the Lusitanian Basin allowed us to understand the relationships and intensity of the energetic agents responsible for the taphonomic changes recorded among the analyzed fossil assemblages. Thus, it was possible to refine the spatial relationships of taphofacies/petrofacies distribution and the corresponding associations in the theoretical 2D models for the distribution of taphofacies for the coquina deposits of the Amaral Formation, and in the 3D models of the depositional systems for each studied sector. 
The biostratigraphic correlation between the Amaral Formation and other units established for the Upper Jurassic of the Lusitanian Basin is still complex and controversial. However, through this investigation, it is possible to recognize different assemblages of preserved elements of the Amaral Formation throughout the Lusitanian Basin, which refers to the different depositional environments referred to above. In this context, the spatial distribution of taphofacies and the corresponding petrofacies represent an important contribution for the establishment of theoretical models for the distribution of taphofacies and 3D models of depositional systems. On the other hand, this work can help the improvement of the predictive capacity in exploration procedures of coquina deposits and the understanding of similar deposits of coquina in the Brazilian pre-salt.

\section{Conclusions}

The studies carried out in the coquina of the Amaral Formation (Lusitanian Basin, Portugal) allowed us to recognize the relevance of using knowledge in the field of evolutionary taphonomy to understand the genesis of the coquina deposits. In this context, different taphonomic processes/mechanisms were identified that led to the recognition of a variety of taphofacies/petrofacies.

The interpretation of the bioestratinomic and fossil-diagenetic processes inherent to the taphonomic alteration allowed for the elaboration of a facies classification and the spatial prediction of coquina facies in any analogous reservoir, as well as the design of theoretical facies distribution models in the context of mixed platforms in different morpho-structural contexts within the same basin.

According to the compositional, textural, and taphonomic aspects, ten taphofacies and four lithofacies were identified for the Amaral Formation, which allowed the definition of 84 petrofacies based on the types and intensity of the identified sedimentary and taphonomic processes and on the diversity of their constituents. Among these, five facies resulted from intense fossil-diagenetic processes, which led to the almost total replacement of the original constituents. Such data, combined with the lateral and vertical variations in each individual outcrop and in all the outcrops, supported the design of paleoenvironmental models of the coquina deposits of the Amaral Formation that illustrate the spatial distribution of the depositional sequences identified by sector (lagoon, lagoon-barrier, and marine-distal).

The analysis of taphofacies and petrofacies of the Amaral Formation allowed the development of theoretical models for their evolution, depending on the paleogeographic and structural contexts, the intensity of the energetic agents, and the fossil diversity. These reflect the rise and fall of the base level, identified through the interpretations of the transgressive-regressive cycles in the studied sections, in the context of a marine environment with the configuration of a gulf. The petrofacies distribution also enables the identification of different marine depositional environments, affected by the action of normal and storm waves and by normal and flood fluvial discharges, the latter responsible for the loading of terrestrial sediments into the carbonate system. In addition, due to the tectonic complexity of the Lusitanian Basin and its intense differential saliferous diapirism, that distribution also reflects the heterogeneity of the platform, which assumes two distinct types: continuous (e.g., Pombal platform at SW, and Berlengas platform at E-SE), and isolated (e.g., Ota platform).

The resulting geological models, related to the Morro do Chaves (Sergipe-Alagoas Basin, NE Brazil) and the Amaral (Lusitanian Basin, Portugal) formations supported the construction of theoretical models of coquina deposits for an ideal bank and platform that allow the adaptation for subsurface analogs, as in the case of contiguous coquina reservoirs in the pre-salt oil province of Brazil. However, the use of such theoretical models in other coquina deposits requires an adequate adjustment to the structural, stratigraphic, and petrographic-petrophysical aspects of the analogue; only then can they have the necessary robustness and reliability for simulation procedures with a low degree of uncertainty. 
The in-depth analysis of the records, in the light of the geological model designed for the Amaral Formation, should lead to its expansion and detailing, making it possible to locate, in the Lusitanian Basin, facies of coquina similar to those already recognized in the Sergipe-Alagoas Basin and in the Brazilian pre-salt. As such, FSRBnob1CmD, FTSRBnob1CmD, FSRBnob1Bob1CmD, FTSRBnob1Bob1CmD, FSRBob1CmD, FTSRBob1CmD, FSRBnob1CmH, FTSRBnob1CmH, FSRBnob1Bob1CmH, FTSRBnob1Bob1CmH, FSRBob1CmH, FTSRBob1CmH, FSRBnob2CmD, FTSRBnob2CmD, FSRBnob2Bob1CmD, FTSRBnob2Bob1CmD, FSRBnob2Bob2CmD, FTSRBnob2Bob2CmD, FSRBob2CmD, and FTSRBob2CmD petrofacies, which present the best quality as reservoir facies, are predictably located in the offshore of the basin.

The methodology underlying the classification of coquina proposed for the Morro do Chaves Formation is valid for the Amaral Formation, with the necessary adaptations resulting from the particular characteristics of the petrofacies recognized in the latter, which exhibit higher diversity in the fossil record and are conditioned by regional tectonics and the most frequent occurrence of transgressive events. Therefore, the particularities of the facies described for the Amaral Formation enabled us to improve the classification of facies for other coquina deposits.

Supplementary Materials: The following are available online at https:/ /www.mdpi.com/article/ 10.3390/jmse9121319/s1, Table S1: Alphanumeric classification of facies types according to their petrographic and taphonomic characteristics identifying types and intensities of processes and products associated with coquina. Table S2: Lithofacies and taphofacies classification of the coquina from Amaral Formation. Table S3: Petrofacies recognized for each sector of the Lusitanian Basin, respective dominant energy conditions, diversity of the fossil record, and relevance of the terrigenous components.

Author Contributions: Conceptualization, G.G.G., A.J.V.G. and M.H.P.H.; methodology, G.G.G.; validation, G.G.G., A.J.V.G. and R.M.M.; investigation, G.G.G., A.J.V.G., M.H.P.H., R.M.M. and R.P.d.R.; writing—original draft preparation, G.G.G.; writing—review and editing, G.G.G., A.J.V.G., M.H.P.H. and R.M.M.; visualization, G.G.G., A.J.V.G., M.H.P.H., R.M.M. and R.P.d.R.; supervision, A.J.V.G., M.H.P.H. and R.P.d.R. All authors have read and agreed to the published version of the manuscript.

Funding: This research was funded by Portuguese funds by Fundação para a Ciência e a Tecnologia, I.P. (Portugal), grant number UIDB/00073/2020 and UIDP/00073/2020, projects of I \& D unit Geosciences Center (CGEO).

Acknowledgments: The authors are grateful to Salomé Custódio and Yasir Shahzad (University of Coimbra, Portugal), for the revision of the manuscript.

Conflicts of Interest: The authors declare no conflict of interest. The funders had no role in the design of the study; in the collection, analyses, or interpretation of data; in the writing of the manuscript, or in the decision to publish the results.

\section{References}

1. Castro, J.C. Evolução dos conhecimentos sobre as coquinas-reservatório da Formação Lagoa Feia no trend Badejo-LinguadoPampo, Bacia de Campos. Geociências (UNESP) 2006, 25, 175-186.

2. Garcia, A.J.V.; Pereira, F.C.; Araújo, W.B.; Rocha, L.M.; Ribeiro, D.D.M.; Leal, F.P.M.; Correia, G.L. Caracterização multiescalar de reservatórios carbonáticos análogos em afloramentos da Bacia de Sergipe-Alagoas, NE do Brasil. In Boletim Técnico da Petrobras; Neto, O.C.P., Ed.; Petrobras: Rio de Janeiro, Brasil, 2014; Volume 22, pp. 51-82.

3. Fernández-López, S. Criterios elementales de reelaboración tafonómica em ammonites de La Cordillera Ibérica. Acta Geol. Hisp. 1984, 19, 105-116.

4. Fernández-López, S. Ammonoid taphonomy, palaeoenvironments and sequence stratigraphy at the Bajocian/Bathonian boundary on the Bas Auran area (Subalpine Basin, south-eastern France). Lethaia 2007, 40, 377-391. [CrossRef]

5. Garcia, A.J.V.; Ribeiro, D.M.; Figueiredo, S.S.; Dantas, M.S.; Oliveira, I.; Leite, K.A.S.; Garcia, G.G. 3D Modeling of carbonate reservoir analogue outcrops using Camures methodology, Sergipe-Alagoas Basin (SEAL), NE, Brazil. In Proceedings of the AAPG Annual Convention \& Exhibition, Denver, CO, USA, 31 May-3 June 2015.

6. Bellian, J.A.; Kerans, C.; Jennette, D.C. Digital outcrop models: Applications of terrestrial scanning lidar technology in stratigraphic modeling. J. Sediment. Res. 2005, 75, 166-176. [CrossRef] 
7. Fabuel-Perez, I.; Hodgetts, D.; Redfern, J. Integration of digital outcrop models (DOMs) and high resolution sedimentologyWorkflow and implications for geological modelling: Oukaimeden Sandstone Formation, High Atlas (Morocco). Pet. Geosci. 2010, 16, 133-154. [CrossRef]

8. Agada, S.; Chen, F.; Geiger, S.; Toigulova, G.; Agar, S.; Benson, G.; Shekhar, R.; Hehmeyer, O.; Amour, F.; Mutti, M.; et al. Deciphering the fundamental controls of flow in carbonates using numerical well-testing, production optimisation, and 3D highresolution outcrop analogues for fractured carbonate reservoirs. In Proceedings of the EAGE Annual Conference \& Exhibition Incorporating SPE Europe, London, UK, 10-13 June 2013.

9. Rodriguez, M.; Abad, F.; Rodriguez, L.; Gaibor, J.; Moran, M.; Verdezoto, A. Application of modern reservoir characterization in mature fields to unravel hidden reserves. In Proceedings of the SPE Latin American and Caribbean Petroleum Engineering Conference, Quito, Ecuador, 18-20 November 2015. [CrossRef]

10. Fernández-López, S. Temas de Tafonomía; Departamento de Paleontología, Faculdade de Ciencias Geológicas, Universidad Complutense de Madrid: Madrid, España, 2000; Unpublished work.

11. Folk, R.L. Spectral subdivision of limestones types. In Classification of Carbonate Rocks-A Symposium; Ham, W.E., Ed.; Geologists Memoir-American Association of Petroleum: Tulsa, OK, USA, 1962; Volume 1, pp. 62-84.

12. Choquette, P.W.; Pray, L.C. Geologic nomenclature and classification of porosity in sedimentary carbonates. AAPG Bull. 1970, 54, 207-250.

13. Garcia, G.G.; Henriques, M.H.; Garcia, A.J.V.; Dantas, M.V.S. Petrofacies and taphofacies analyses of coquinas as a tool for the establishment of a stratigraphic evolution model of the Morro do Chaves Formation (Sergipe-Alagoas Basin, NE Brazil). Facies 2020, 67, 4. [CrossRef]

14. Ribeiro, A.; Antunes, M.T.; Ferreira, M.P.; Rocha, R.B.; Soares, A.F.; Zbyszewski, G.; Moitinho de Almeida, F.; de Carcalho, D.; Monteiro, J.H. Introduction à la géologie générale du Portugal. Servi. Geológ. Portug. 1979, 72, 1-114.

15. Wilson, R.C.L. Mesozoic development of the Lusitanian Basin, Portugal. Rev. Soc. Geol. Esp. 1988, 1, $393-407$.

16. Kullberg, J.C.; Rocha, R.B.; Soares, A.F.; Rey, J.; Terrinha, P.; Azerêdo, A.C.; Callapez, P.; Duarte, L.V.; Kullberg, M.C.; Martins, L.; et al. A Bacia Lusitaniana: Estratigrafia, Paleogeografia e Tectónica. In Geologia de Portugal—Geologia Meso-Cenozóica de Portugal; Dias, R., Araújo, A., Terrinha, P., Kullberg, J.C., Eds.; Livraria Escolar Editora: Forte da Casa, Portugal, 2013; Volume 2, pp. 317-368.

17. Rocha, R.B.; Marques, B.L.; Kullberg, J.C.; Caetano, P.C.; Lopes, C.; Soares, A.F.; Duarte, L.V.; Marques, J.F.; Gomes, C.R. The 1st and 2nd Rifting Phases of the Lusitanian Basin: Stratigraphy, Sequence Analysis and Sedimentar Evolution; Final Report; C. E. C. Proj. MILUPOBAS: Lisboa, Portugal, 1996.

18. Pena dos Reis, R.B.; Trincão, P.R.P.; Cunha, P.M.R.P.; Dinis, J.M.L. Resumo do Estado Actual de Conhecimentos Sobre o Jurássico Superior da Bacia Lusitânica; Relatório Técnico-Científico BAG: Coimbra, Portugal, 1993.

19. Garcia, A.J.V.; Pimentel, N.; Pena dos Reis, R. Projeto Atlantis: "Modelo Geológico Evolutivo Para os Riftes Marinhos do Jurrásico da Bacia Lusitânica (Portugal); Relatório 04 PETROBRAS-UFS/FAPESE-UC/IPN-UL/FFCUL: Aracaju, Brasil, 2010; Unpublished work.

20. Pena dos Reis, R.B.; Pimentel, N.L.; Garcia, A.J.V. A Bacia Lusitânica (Portugal): Análise estratigráfica e evolução geodinâmica. In Boletim de Geociências da Petrobras: Bacia Lusitânica; Milani, E.J., Zalán, P.V., Spadini, A.R., Machado, D.L., Jr., Silva, E.F.F., Terra, G.J.S., Bueno, G.V., Eds.; Petrobras: Rio de Janeiro, Brasil, 2010; Volume 19, pp. 23-52.

21. Pena dos Reis, R.B.; Cunha, P.M.R.; Dinis, J.L.; Trincão, P. Geologic evolution of Lusitanian Basin during Late Jurrasic (Portugal). In Advances in Jurassic Research; Hall, R.L., Smith, P.L., Eds.; GeoResearch Forum-Trans Tech Pub: Zurich, Switzerland, 2000; Volume 6, pp. 345-356.

22. Pena dos Reis, R.B.; Pimentel, N.; Bueno, G. III Curso de Campo na Bacia Lusitânica (Portugal), 3rd ed.; Impressão e Soluções, Laboratório de imagem, LDA: Coimbra, Portugal, 2008; p. 136. ISBN 978-989-20-0423-5.

23. Ramalho, M.M. Contribution à l'étude micropaléontologique et stratigraphique du Jurassique supérieur et du Crétace inférieur des environs de Lisbonne (Portugal). Serv. Geol. Port. 1971, 19, 1-212.

24. Choffat, P. Limite entre le Jurassique et le Crétacique. Notice Préliminaire. In Extrait du Bulletin de la Société Belge de Géologie de Paléontologie et D'Hydrologie; Hayez, Imprimeur de L'Académie Royale de Belgique: Bruxelles, Belgium, 1901; Volume XV, pp. 111-140.

25. Seifert, H. Beiträge zur geologie der Serra da Arrábida in Portugal. Geol. Jahrb. 1963, 81, 277-344.

26. Wilson, R.C.L. A reconnaissance study of Upper Jurassic sediments of the Lusitanian Basin. Ciênc. Terra 1979, 5, $53-85$.

27. Teixeira, C.; Gonçalves, F. Introdução à Geologia de Portugal; Instituto Nacional de Investigação Científica: Lisboa, Portugal, 1980.

28. Leinfelder, R.R.; Nose, M.; Schmid, D.; Werner, W. Reefs and carbonate platforms in a mixed carbonate-siliciclastic setting Examples from the Upper Jurassic (Kimmeridgian to Tithonian) of west-central Portugal. In Proceedings of the 23rd IAS Meeting of Sedimentology, Coimbra, Portugal, 15-17 September 2004; Duarte, L.V., Henriques, M.H., Eds.; Sedimentology and Society; Field Trip Guidebook-Carboniferous and Jurassic Carbonate Platforms of Iberia. Volume 1, pp. 95-123.

29. Leinfelder, R.R. Upper Jurassic Reefs and Controlling Factos-A preliminar Report; Profile: London, UK, January 1993; Volume 5, pp. 1-45.

30. Leinfelder, R.R. Distribution of Jurassic reef types: A mirror of structural and environmental changes during breakup of Pangea. In Pangea: Global Environments and Resources; Embry, A.F., Beauchamp, B., Glass, D.J., Eds.; Canadian Society of Petroleum Geologists Memoir: Calgary, AB, Canada, 1994; Volume 17, pp. 677-700.

31. Leinfelder, R.R. Jurassic Reef Ecosystems. In The History and Sedimentology of Ancient Reef Systems; Stanley, G.D., Jr., Ed.; Plenum Press: New York, NY, USA, 2001; pp. 251-309. 
32. Leinfelder, R.R.; Krautter, M.; Nose, M.; Ramalho, M.M.; Werner, W. Siliceous sponge fácies from Upper Jurassic of Portugal. Neues Jahrb. Geol. Paläontol. Abh. 1993, 189, 199-254.

33. Leinfelder, R.R.; Nose, M.; Schmid, D.U.; Werner, W. The importance of microbial crusts in Upper Jurassic reef information. Facies 1993, 29, 195-230. [CrossRef]

34. Leinfelder, R.R.; Werner, W.; Nose, M.; Schmid, D.U.; Krautter, M.; Laternser, R.; Takacs, M.; Hartmann, D. Paleoecology, growth parameters and Dynamics of coral, sponge and microbolite reefs from the Late Jurassic. Göttinger Arb. Geol. Paläont. 1996, 2, $227-248$.

35. Fürsich, F.T.; Werner, W.; Schneider, S. Autochthonous to parautochthonous bivalve concentrations within transgressive marginal marine strata of the Upper Jurassic of Portugal. Palaeobiodiversity Palaeoenvironments 2009, 89, 161-190. [CrossRef]

36. Fernández-López, S. Taphonomic concepts for a theoretical biochronology. Rev. Esp. Paleontol. 1991, 6, 37-49.

37. Fernández-López, S.R.; Meléndez, G. Fossilization of ammonites and sedimentary events in deep environments of carbonate platform (highest middle to lowest Upper Oxfordian, Iberian Range, Spain). Riv. Ital. Paleontol. Stratigr. 2004, 110, $219-229$.

38. Pena dos Reis, R.; Trincão, P.; Cunha, P.P.; Dinis, J.L. Relatório Final de Execução do Projecto "Estratigrafia Sequencial e Biostratigrafia do Jurássico Superior da Bacia Lusitânica"; GPEP: Coimbra, Portugal, 1995.

39. Garcia, G.G.; Campos, M.F.; Henriques, M.H.; Pena dos Reis, R.; Garcia, A.J.V. As coquinas da formação amaral da Bacia Lusitânica (Kimmeridgiano; Portugal): Uma abordagem multidisciplinary. In Livro de Resumos do Paleo Fall Meeting, 1st ed.; Fialho, P., Silva, R., Eds.; Universidade de Évora: Évora, Portugal, 2019; Volume 1, p. 9. ISBN 978-972-778-124-9.

40. Choffat, P. Recueil de monographies stratigraphiques sur le Système Crétacique du Portugal. Première étude. Contrées de Cintra, Bella set de Lisbonne. Mem. Sec. Trab. Geol. Port. 1885, 1, 1-68.

41. Choffat, P. Description de la faune jurassique de Portugal. Mollusques lamellibranches, 2. ${ }^{a}$ ordre, Asiphonidae, 2ème livraison. Mem. Dir. Trab. Geol. Port. 1885, 2, 1-36.

42. Choffat, P. Recherches sur les Terrains Secondaires au Sud de Sado. Com. Trab. Geol. Port. 1887, 1, $222-312$.

43. Choffat, P. Contributions à la connaissance géologique des sources minéro-thermales des aires mésozoïques du Portugal. Impre Nacio. 1893, 1, 1-136.

44. Choffat, P. Description de la faune jurassique du Portugal. Classe des Céphalopodes, 1ère série: Ammonites du Lusitanien de la contrée de Torres Vedras. Mem. Dir. Trab. Geol. Port. 1893, 1, 1-82.

45. Fürsich, F.T.; Schneider, S.; Werner, W.; Lopez-Mir, B.; Pierce, C.S. Life at the continental-marine interface: Palaeoenvironments and biota of the Alcobaça Formation (Late Jurassic, Central Portugal), with a formal definition of the unit appended. Palaeobiodiversity Palaeoenvironments 2021, 1-65. [CrossRef] 